2014

\title{
Third Party Funding of Personal Injury Tort Claims: Keep the Baby and Change the Bathwater
}

Terrence Cain

University of Arkansas at Little Rock William H. Bowen School of Law, txcain@ualr.edu

Follow this and additional works at: http://lawrepository.ualr.edu/faculty_scholarship

Part of the Torts Commons

\section{Recommended Citation}

Terrence Cain, Third Party Funding of Personal Injury Tort Claims: Keep the Baby and Change the Bathwater, 89 Chi.-Kent L. Rev. 11 (2014).

This Article is brought to you for free and open access by Bowen Law Repository: Scholarship \& Archives. It has been accepted for inclusion in Faculty Scholarship by an authorized administrator of Bowen Law Repository: Scholarship \& Archives. For more information, please contact mmserfass@ualr.edu. 


\title{
THIRD PARTY FUNDING OF PERSONAL INJURY TORT CLAIMS: KEEP THE BABY AND CHANGE THE BATHWATER
}

\author{
TERRENCE CAIN*
}

\section{INTRODUCTION}

On any given day in the United States, scores of persons are injured as a result of the negligence of others. ${ }^{1}$ If the injured person wishes to be made whole by the party who injured her, she has to sue the tortfeasor or settle the matter out of court. ${ }^{2}$ Neither option is particularly attractive or advantageous for the injured person for at least two reasons. ${ }^{3}$ First, litigation inevitably involves delay and uncertainty, both of which are problematic for impecunious tort victims because they literally cannot afford to wait on the outcome of a lawsuit that they may or may not win or that might result in a monetary recovery far below what they expect. ${ }^{4}$ Second, in order to avoid the uncertainty and delay associated with litigation, some injured persons settle cases for far less than what they could obtain from a verdict or judgment. 5

Before the advent of Litigation Finance Companies ("LFCs"), if a tort victim found herself unable to work as a result of another's negligence and she lacked sufficient cash, savings, or other liquid assets, she might not be able to pay for health care, food, housing, transportation, and the myriad of other expenses that come with living from day to day. ${ }^{6}$ Tort plaintiffs in

\footnotetext{
* Associate Professor Law, University of Arkansas at Little Rock William H. Bowen School of Law. I am extremely grateful to Professor Sarah Howard Jenkins for the support and guidance she provided as I wrote this article as well as throughout my teaching career. I also want to thank the University of Arkansas at Little Rock William H. Bowen School of law, which provided a research grant for the article.

1. Marc J. Shukaitis, A Market in Personal Injury Tort Claims, 16 J. Legal Stud. 329, 329 (1987).

2. Id.

3. Id.

4. Jenna Wims Hashway, Litigation Loansharks: A History of Litigation Lending and a Proposal to Bring Litigation Advances Within the Protection of Usury Laws, 17 ROGER WILLIAMS U. L. ReV. 750, 751 (2012); Martin J. Estevao, Note, The Litigation Financing Industry: Regulation to Protect and Inform Consumers, 84 U. COLO. L. REV. 467, 468-69 (2013).

5. Hashway, supra note 4, at 751; Susan Lorde Martin, The Litigation Financing Industry: The Wild West of Finance Should be Tamed not Outlawed, 10 FordHAM J. CORP. \& FIN. L. 55, 56 (2004); Shukaitis, supra note 1, at 329; Estevao, supra note 4, at 468-69.

6. Hashway, supra note 4, at 751; Martin, supra note 5, at 55-56; Shukaitis, supra note 1, at 329; Estevao, supra note 4, at 468-69.
} 
need of money to meet life's daily expenses cannot turn to conventional lenders and obtain loans using their potential tort recovery as collateral because conventional lenders deem such loans as too risky. ${ }^{7}$ LFCs stepped into this market void by offering cash advances to tort plaintiffs in exchange for a portion of the proceeds of their lawsuits if and when they obtained a settlement, judgment, or verdict. ${ }^{8}$ LFCs advance funds on a nonrecourse basis, meaning a plaintiff does not have to repay what she borrowed unless she actually receives proceeds from her lawsuit; if she loses her case, she does not owe the LFC anything. ${ }^{9}$

On the other hand, if she does recover something from her lawsuit, she could very well end up owing the LFC as much as $280 \%$ more than what she borrowed. ${ }^{10}$ If she recovers less than what she owes the LFC, she will have to turn her entire recovery over to the LFC, leaving her with nothing. ${ }^{11}$ The interest rates LFCs charge to fund lawsuits vary, but it is not atypical for an LFC to charge $80 \%$ interest in the first year of a loan and up to $280 \%$ of the total loan amount. 12

LFCs have been the subject of stinging criticism, the crux of which is they foment litigation abuse by increasing the number of non-meritorious cases filed; they interfere with the attorney-client relationship because their

7. Susan Lorde Martin, Financing Litigation On-Line: Usury and Other Obstacles, 1 DePAUL Bus. \& COM. L.J. 85, 85 (2002).

8. Hashway, supra note 4, at 751-52; Martin, supra note 5, at 55-56; Estevao, supra note 4, at 469-70

9. Hashway, supra note 4, at 751-52; Martin, supra note 5, at 55-56; Estevao, supra note 4, at 469-70.

10. Hashway, supra note 4, at 751; Martin, supra note 7, at 98 .

11. Hashway, supra note 4, at 751. In 1995, a woman injured in a car accident outside of Philadelphia, Pennsylvania hired an attorney to sue the tortfeasor. Binyamin Appelbaum, Investors Put Money on Lawsuits to Get Payouts, N.Y. TIMES, Nov. 14, 2010, http://www.nytimes.com/2010/11/15/business/15lawsuit.html?pagewanted=all\&_r=0. Both she and her lawyer obtained advances from LFCs. Id. Eight years after the accident, she won $\$ 169,125$, but owed the LFCs $\$ 221,000$. Id. By way of contrast, consider the case of Abner Louima ("Mr. Louima"). Sewell Chan, The Abner Louima Case, 10 Years Later, N.Y. Times, Aug. 9, 2007, http://cityroom.blogs.nytimes.com/2007/08/09/the-abner-louima-case-10-years-later/?_r=0. In 1997, New York City police officers arrested Mr. Louima for a crime he did not commit. Id. One of those officers, Justin A. Volpe, "rammed a broken broomstick into Mr. Louima's rectum" and then jammed it into his mouth. Id. The brutal attack ruptured Mr. Louima's bladder and colon, and caused him to be hospitalized for two months. Id. Mr. Louima sued the City of New York and the police union, and in 2001 he settled with the city for $\$ 7.125$ million and with the union for $\$ 1.625$ million. David M. Herszenhorn, The Louima Ruling; Chronology of the Case, N.Y. TIMES, Mar. 1, 2002, http://www.nytimes.com/2002/03/01/nyregion/the-louima-ruling-chronology-of-the-case.html. In 2000, however, lacking funds to pay his living expenses, Mr. Louima contacted LawCash, a Brooklyn, New York based LFC, and obtained a \$20,000 advance. Martin, supra note 5, at 74. LawCash charged Mr. Louima an annual interest rate of $16 \%$. Id. After he received his settlement proceeds, Mr. Louima repaid LawCash. Id.

12. Hashway, supra note 4, at 751; Martin, supra note 7, at 98; Appelbaum, supra note 11; Binyamin Appelbaum, Lobby Battle Over Loans for Lawsuits, N.Y. TIMES, Mar. 9, 2011, http://www.nytimes.com/2011/03/10/business/10lawsuits.html?pagewanted=all. 
desire to maximize their investment leads to their exerting control over plaintiffs' cases; they undermine attorney-client privilege because they demand disclosure of confidential information about a case or a plaintiff in order to determine whether to advance money to a plaintiff; and they exploit vulnerable, desperate, and unsophisticated persons. ${ }^{13}$

LFCs have their defenders, and they counter the critics by pointing out that LFCs provide tort victims who have meritorious claims with the resources necessary to pursue those claims when they otherwise would not because of a lack of money; LFCs bring plaintiffs some measure of monetary parity in litigation against well-heeled defendants, such as those defended by insurance companies; and plaintiffs who can tap into LFC advanced funds while their litigation is pending are in a stronger bargaining position because they have less incentive to settle a case for an artificially low amount out of fear that if the case lingers they will run out of money to live on from day to day. ${ }^{14}$ No matter where one comes down on the question of whether third party litigation funding 15 is a net positive or a net

13. John P. Barylick \& Jenna Wims Hashway, Litigation Financing: Preying on Plaintiffs, R.I. BAR JournaL, March/April 2011, at 5; Jeremy Kidd, To Fund or Not to Fund: The Need for SecondBest Solutions to the Litigation Finance Dilemma, 8 J.L. ECON. \& POL'Y 613, 627-35 (2012); Geoffrey J. Lysaught \& D. Scott Hazelgrove, Economic Implications of Third-Party Litigation Financing on the U.S. Civil Justice System, 8 J.L. ECON. \& POL’Y 645, 654-55 (2012); Ronald C. Minkoff \& Andrew D. Patrick, Taming the Champerty Beast: A Proposal for Funding Class Action Plaintiffs, 15 No. 1 Prof. LAW. 1, 5, 6 (2004); Paul H. Rubin, Third-Party Financing of Litigation, 38 N. KY. L. REV., 673, 68185 (2011); Joanna M. Shepherd, Ideal Versus Reality in Third-Party Litigation Financing, 8 J.L. ECON \& POL’y 593, 599-609 (2012); John Beisner, Jessica Miller \& Gary Rubin, Selling Lawsuits, Buying Trouble: Third-Party Litigation Funding in the United States, U.S. CHAMBER INST. FOR LEGAL REFORM, Oct. 2009, at 1-8.

14. Garber, infra note 15, at 29-46; Martin, supra note 7, at 95-102; Susan Lorde Martin, Financing Plaintiffs' Lawsuits: An Increasingly Popular (and Legal) Business, 33 U. Mich. J.L. ReFoRM 57, 84-86 (1999-2000); Susan Lorde Martin, Litigation Financing: Another Subprime Industry that Has a Place in the United States Market, 53 VILL. L. REv. 83, 102 (2008); Susan Lorde Martin, Syndicated Lawsuits: Illegal Champerty or New Business Opportunity?, 30 AM. Bus. L.J. 485, 507-08 (1992); Martin, supra note 5, at 67-77; Anthony J. Sebok, Betting on Tort Suits After the Event: From Champerty to Insurance, 60 DePAul L. REV. 453, 453-72 (2011); Anthony J. Sebok, The Inauthentic Claim, 64 VAND. L. REV. 61, 63-72, 120-37 (2011).

15. Steven Garber, who authored Alternative Litigation Financing in the United States, RAND CORP., http://www.rand.org/content/dam/rand/pubs/occasional_papers/2010/RAND_OP306.pdf, takes exception to the use of the phrase "third party financing of litigation." Id at ix. He says it mischaracterizes the practice because it is based on the false premise that the plaintiff and the defendant are the first two and only two parties involved in a particular lawsuit. Id. In nearly all personal injury lawsuits, plaintiffs are represented by lawyers working on a contingency fee basis who in turn advance the costs of the litigation and get reimbursed only if the plaintiff recovers something from the lawsuit. Id. Similarly, defendants often rely on insurance to pay their costs of litigation. Id. Because contingency fee lawyers and insurance companies are as much a part of personal injury litigation as the plaintiffs and defendants, Mr. Garber asserts that the phrase "alternative litigation financing" should be used because it more accurately reflects the practice of litigation being funded "by entities other than plaintiffs, defendants, their lawyers, or defendants' insurers." Id . While not questioning or quarreling with Mr. Garber's reasoning or conclusion on this point, this article will refer to the practice as "third party litigation funding" or "third party litigation financing." 
negative in the civil litigation system, all can probably agree that it is highly unlikely that this industry is going to disappear in the foreseeable future. Likewise, all should agree that the industry is unregulated for the most part. ${ }^{16}$

The federal government does not regulate LFCs at all, and only Maine, ${ }^{17}$ Ohio, ${ }^{18}$ and Nebraska ${ }^{19}$ regulate them in their respective states. The State of New York has a quasi-regulatory regime in the form of a 2005 agreement between the Attorney General of the State of New York and nine LFCs regarding certain practices of those specific LFCs in the State. ${ }^{20}$ In 2004, a group of LFCs formed a trade association called the American Legal Finance Association ("ALFA") "to establish industry standards in the

16. Yifat Shaltiel \& John Cofresi, Litigation Lending for Personal Needs Act: A Regulatory Framework to Legitimatize Third Party Litigation Finance, 58 CONSUMER FIN. L. Q. REP. 347, 347-49 (2004); Sheri P. Adler, Note, Alternative Litigation Finance and the Usury Challenge: A Muli-Factor Approach, 34 CARDOZO L. REV. 329, 331 (2012); Courtney R. Barksdale, Note, All That Glitters Isn't Gold: Analyzing the Costs and Benefits of Litigation Finance, 26 REV. LITIG. 707, 707-10 (2007); Nicholas Beydler, Comment, Risky Business: Examining Approaches to Regulating Consumer Litigation Funding, 80 UMKC L. REV. 1159, 1159-62 (2012); Ari Dobner, Comment, Litigation for Sale, 144 U. PA. L. REV. 1529, 1529-31 (1996); Lauren J. Grous, Note, Causes of Action for Sale: The New Trend of Legal Gambling, 61 U. MiAmi L. REV. 203, 230-36 (2006); Mariel Rodak, Comment, It's About Time: A Systems Thinking Analysis of the Litigation Finance Industry and its Effect on Settlement, 155 U. PA. L. Rev. 503, 503-09 (2006); Kingston White, Note, A Call for Regulating Third-Party Divorce Litigation Funding, 13 J.L. \& FAM. STUD. 395, 395-97 (2011).

17. The Maine Consumer Credit Code Legal Funding Practices. ME. REv. Stat. tit. 9-A, §§ 12101 to -107 (2012).

18. OHIo Rev. Code ANn. § 1349.55 (West 2012). 2013).

19. The Nonrecourse Civil Litigation Act, Neb. Rev. Stat. AnN. §§ 25-3301 to -3309 (West

20. Bureau of Consumer Frauds and Protection, Attorney Gen. of the State of N.Y., Assurance of Discontinuance Pursuant to Executive Law § 63(15) 4-7 (2005) [hereinafter N.Y. Assurance of Discontinuance], available at http://www.americanlegalfin.com/alfasite2/documents/ALFAAgreement WithAttorneyGeneral.pdf. The Nine LFCs who signed off on the agreement are: Plaintiff Support Services, Inc.; Pre-Settlement Finance, LLC; QuickCash, Inc.; Magnolia Funding, LLC; BridgeFunds Limited; Plaintiff Funding Corporation d/b/a LawCash; Oasis Legal Finance Co., LLC; The Whitehaven Group, LLC; New Amsterdam Capital Partners LLC d/b/a LawMax. Id. at 1-2. One New York court expressed its dismay at the Attorney General for giving LFCs his "blessing." Echeverria v. Estate of Linder, No. 018666/2002, 2005 WL 1083704, at *8 (N.Y. Sup. Ct. Mar. 2, 2005) ("While the Attorney General seems to have given these types of funding institutions his blessing through signing an agreement with them, the Court feels that the effects of these types of institutions on the legal system and the judiciary need to be examined in further detail in order to determine whether this type of business practice is more of a benefit or detriment to society as a whole."). One of the issues the court addressed in Echeverria was whether the advance the plaintiff received from LawCash - one of the signatories to the Attorney General's Agreement - constituted champerty. Echeverria, 2005 WL 1083704 , at $* 1$. LawCash advanced the plaintiff $\$ 25,000$ at an interest rate of $3.85 \%$ per month. Id. Although the court concluded that LawCash had not engaged in champerty, it did conclude that charging interest at a rate of $3.85 \%$ per month or $60 \%$ per annum was usurious. Id. at $3,5-8$. The court also said it would be "ludicrous" to consider the $\$ 25,000$ transaction "anything else but a loan unless the court was to consider it legalized gambling." Id. at 8 . The court concluded by saying, "If the Attorney General was to formally legalize these arrangements by an 'opinion letter' rather than merely allow them to operate pursuant to an 'agreement' [that] makes their operation safer to the consumer, that would be appreciated by the court." Id. The Attorney General of the State of New York has yet to issue an opinion letter with respect to LFCs. 
Legal Funding industry, especially regarding transparency in transactions and clear disclosure to consumers." 21 ALFA's primary focus, however, is not regulating its members but lobbying state legislatures to leave the industry alone. ${ }^{22}$ It is against this backdrop of little to no governmental oversight that led one LFC's owner to describe the industry as "the Wild West of finance." 23

The interest rates LFCs charge borrowers are staggeringly high, and many, but certainly not all, of the people who seek funding from LFCs do so when they are in dire financial straits. ${ }^{24}$ The intersection of injured tort plaintiffs desperate for money and wealthy interests seeking to make money off of tort litigation creates a scenario that can lead to the exploitation of tort plaintiffs, which is one of the reasons critics of LFCs think they should be abolished. 25 On the other hand, the United States of America is a country that prides itself on individuals having the freedom to enter into any lawful transaction they wish, so long as the parties to the transaction are fully informed and act of their own free will. ${ }^{26}$ This is a core point of the defenders of LFCs. ${ }^{27}$

LFCs should be regulated just like banks, credit card issuers, payday lenders, and lenders in the fringe credit industry. ${ }^{28} \mathrm{~A}$ reasonable regulatory regime strikes the proper balance between the abolition of the industry, which is unlikely to happen, and the "Wild, Wild, West," which is what exists now. A regulatory regime enacted and enforced by the federal government would be more efficient and effective than leaving it up to indi-

21. Marco de Morpurgo, A Comparative Legal and Economic Approach to Third-Party Litigation Funding, 19 CARDOZO J. INT'L \& COMP. L. 343, 358-59 (2011); Facts About ALFA, AMERICANLEGALFin.com (last visited Oct. 15, 2013), http://www.americanlegalfin.com/ FactsAboutALFA.asp.

22. Estevao, supra note 4, at 477-78

23. Martin, supra note 5, at $55 \mathrm{n} .2$ (citing Michael Pollick, Business \& Money: Betting on the Verdict; Lawyers Advance Plaintiffs Money to Keep Lawsuits Going, in Hopes of Cashing in if a Suit Succeeds, THE GADSDEN TIMES, Feb. 9, 2003, at E2 (quoting David Schechter, owner of ExpressLawsuitFunding.com, a web-site designed to offer financing to plaintiffs with limited resources)).

24. Hashway, supra note 4, at 751-52; Martin, supra note 5, at 56, 74-75; Estevao, supra note 4, at $468-69$.

25. Beisner, Miller \& Rubin, supra note 13, at 5, 8-9.

26. This is evident in the law. For example, the Supreme Court of the United States articulated the definition of "fair market value" in United States v. Cartwright, 411 U.S. 546, 551 (1973), where the Court said "The fair market value is the price at which the property would change hands between a willing buyer and a willing seller, neither being under any compulsion to buy or to sell and both having reasonable knowledge of relevant facts." Id. (quoting Treas. Reg. § 20.2031-1(b)).

27. Hashway, supra note 4, at 760; Martin, supra note 5, at 56, 74-77; Estevao, supra note 4, at 492-96.

28. Diane Hellwig, Note, Exposing the Loansharks in Sheep's Clothing: Why Re-Regulating the Consumer Credit Market Makes Economic Sense, 80 Notre Dame L. Rev. 1567, 1567, 1569 (2005). The fringe credit industry is comprised of creditors that provide loans that conventional lenders will not because the loans are too small or too risky. Id. 
vidual states to craft a hodgepodge of idiosyncratic laws. The United States needs a uniform set of rules that every LFC must follow. This has the added advantage of providing every potential borrower of LFC funds with the same baseline level of protection rather than having one's rights determined according to the legislative vicissitudes of the states.

Part One of this article will briefly detail the history of LFCs. Part Two discusses the law of assignment, maintenance, champerty, and barratry and how they apply to LFCs. Part Three explores the legal status of LFCs in each of the states. Part Four analyzes the regulatory regimes in New York, Maine, Ohio, and Nebraska. Part Five concludes with a proposal that the Consumer Financial Protection Bureau, the Federal Trade Commission, or both adopt a regulatory regime modeled after a combination of what has been adopted in New York, Maine, Ohio, and Nebraska.

\section{A BRIEF HISTORY OF LFCS}

Who started the first LFC is a contested matter, but the name frequently associated with being the industry's founder is Perry Walton ("Mr. Walton"). ${ }^{29}$ Mr. Walton's story reads like a subplot from the Martin Scorsese and Nicholas Pileggi film "Casino." 30 A former rock musician and mobile home park developer, Mr. Walton opened a loan sharking business in Las Vegas, Nevada that he dubbed "Wild West Funding." 11 In 1997, he pleaded guilty to extortion after several of his borrowers complained to police about his collection tactics. ${ }^{32} \mathrm{He}$ received a sentence of eighteen months' probation, and in 1998, he opened "Future Settlement Funding Corp.," for the purpose of advancing money to plaintiffs in lawsuits. ${ }^{33}$ In order to inoculate himself against Nevada's usury laws, Mr. Walton categorized his advances as "contingent obligations" rather than loans, the distinction being the advances he made were contingent upon the outcome of the under-

29. Hashway, supra note 4, at 753-54; Lysaught \& Hazelgrove, supra note 13, at 649; Martin, supra note 5, at 70; Julia H. McLaughlin, Litigation Funding: Charting a Legal and Ethical Course, 31 VT. L. REV. 615, 618-19 (2007); Shaltiel \& Cofresi, supra note 16, at 347; George Steven Swan, Economics and the Litigation Funding Industry: How Much Justice Can You Afford?, 35 NEW ENG. L. REV. 805, 825-26; (2001); Beydler, supra note 16, at 1162; Nicholas Dietsch, Note, Litigation Financing in the U.S., the U.K., and Australia: How the Industry has Evolved in Three Countries, 38 N. KY. L. REV. 687, 691 at n. 35 (2011); Grous, supra note 16, at 206-7; Rodak, supra note 16, at 505-06. Alan Zimmerman, who started an LFC in 1994 in San Francisco, California, is also considered a founder of the industry. Appelbaum, supra note 11. Others include a mortgage salesman from Buffalo, New York and a subprime automobile lender from Nashville, Tennessee. Id.

30. CASINO (MCA/Universal Pictures 1995).

31. Richard B. Schmitt, Staking Claims: A Las Vegas Lender Tests Odds in Court-And Forms an Industry, WALL St. J., Sept. 15, 2000, at A1.

32. Hashway, supra note 4, at 754 .

33. Id. 
lying litigation and therefore were not loans because borrowers did not have an absolute obligation to repay. ${ }^{34}$ That is, when a plaintiff receives something from her lawsuit, her obligation to repay the LFC is triggered, and she often ends up paying as much as $280 \%$ more than she borrowed. ${ }^{35}$ Mr. Walton also began offering seminars to persons interested in getting in on the lawsuit funding business, charging attendees as much as $\$ 12,400$ each. ${ }^{36}$ By 2000, 400 persons had attended Mr. Walton's seminars, and LFCs started multiplying. ${ }^{37}$

Determining exactly how many LFCs currently exist is probably impossible because except in the states of Maine ${ }^{38}$ and Nebraska, ${ }^{39}$ there are no registration requirements for LFCs. 40 The industry's lobbying arm, ALFA, consists of thirty-one LFCs. ${ }^{41}$ Together, these LFCs advance plaintiffs approximately $\$ 100$ million per year and have a total investment portfolio in excess of $\$ 1$ billion. ${ }^{42}$ It would be a mistake, however, to assume that LFCs only advance money to hapless, cash strapped, unsophisticated personal injury tort plaintiffs. Some of the most famous, influential, and wealthy white shoe law firms in the country have introduced their clients to LFCs. ${ }^{43}$ These firms include Simpson Thacher \& Bartlett; Latham \& Watkins; Fulbright \& Jaworski; and Patton Boggs. 44

John Coffey, co-founder of the LFC BlackRobe Capital, says that BlackRobe's typical borrower is a top twenty-five law firm. ${ }^{45}$ In 2012, Burford Capital Limited, one of the larger LFCs, expected to make $\$ 32$ million off of nine cases, which represented a return on investment of 91\%. 46 One of those nine cases involved a plaintiff represented by a partner with Simpson Thacher \& Bartlett. 47 The plaintiff won a verdict of $\$ 110$ million, but the parties settled the case, and Burford Capital Limited ex-

34. Id.; Adler, supra note 16, at 334-35.

35. Hashway, supra note 4, at 751; McLaughlin, supra note 29, at 620-21.

36. Hashway, supra note 4 , at 754 .

37. Id.

38. ME. Rev. STAT. tit. 9-A, § 12-106(1) (2012).

39. Neb. Rev. Stat. AnN. § 25-3307(1) (West 2013).

40. Hashway, supra note 4, at 754; McLaughlin, supra note 29, at 622.

41. Facts About ALFA, http://www.americanlegalfin.com/FactsAboutALFA.asp (last visited September 16, 2013).

42. Appelbaum, supra note 11; Appelbaum, supra note 12.

43. Debra Cassens Weiss, Top Law Firms Turn to Litigation Finance Companies to Fund Suits, ABAJ. (May 1, 2012, 8:35 AM), http://www.abajournal.com/news/article/top_law_firms_turn_ to_litigation_finance_companies_to_fund_suits/.

44. Id.

45. $I d$.

46. $I d$.

47. Id. The plaintiff, a real estate developer, sued a competitor for allegedly attempting to block one of its projects. 
pected to make $\$ 18$ million off of the $\$ 6$ million advance it made to the plaintiff. 48

LFCs do not just loan money to plaintiffs involved in personal injury tort lawsuits. The two largest LFCs in the United States, Juridica Capital Management and Burford Capital Limited, focus their funding on largescale commercial litigation. 49

Juridica Capital Management invests only in commercial cases and has a worldwide presence. ${ }^{50}$ Its literature says it "does not arrange finance for personal injury claims or for mass tort claims, except in special circumstances." 51 In a December 2007 initial public offering, Juridica Investments Limited, which is managed by Juridica Capital Management, raised $£ 74$ million in an initial public offering on the Alternative Investment Market of the London Stock Exchange. ${ }^{52}$ In a second offering in 2009, it raised $£ 33.2$ million. 53 Since it began trading on the London Stock Exchange, Juridica Investments Limited's share price has grown by $24 \%$ and its annual return on investment exceeds 20\%.54 Burford Capital Limited limits its investments to commercial lawsuits, and describes its "core business" as commercial litigation in the United States and international arbitration. 55

While conventional banks do not loan funds to litigants whose only source of collateral consists of the potential proceeds from a lawsuit, some banks do finance LFCs. ${ }^{56}$ Citigroup, Commerce Bank of New Jersey, and Credit Suisse have all provided funding to LFCs. ${ }^{57}$ From its beginnings in the early 1990s, third party litigation funding has grown into a \$1 billion industry. ${ }^{58}$ Any industry that grows that fast and is that lucrative while remaining largely unregulated is bound to generate considerable controversy, and where there is controversy there is bound to be academic commentary supporting the industry, opposing it, or taking a position somewhere between support and opposition. The commentary on third party litigation

48. Id.

49. Michelle Boardman, Insurers Defend and Third Parties Fund: A Comparison of Litigation Participation, 8 J.L. ECON. \& POL'Y 673, 676-77 (2012).

50. Id. at 676 .

51. Id. (citation omitted).

52. Id.; Beisner, Miller \& Rubin, supra note 13, at 3.

53. Beisner, Miller \& Rubin, supra note 13, at 3.

54. Id.

55. Boardman, supra note 49, at 677.

56. Appelbaum, supra note 11.

57. Id.

58. Id. 
funding and all of its social, political, moral, and legal implications is copious. 59

An indispensable component of the business model of the LFC is a plaintiff who has the lawful authority to convey her interest in her lawsuit to the LFC. The next part of this article will discuss how in certain instances, the law allows plaintiffs to do just that.

\section{THE LAW OF ASSIGNMENT, MAINTENANCE, CHAMPERTY, AND BARRATRY}

\section{A. Assignment}

In order to fully understand how third party litigation funding works, one must understand the doctrines of assignment, maintenance, champerty, and barratry. An assignment is a transfer of property or a right from one person (the assignor) to another (the assignee). ${ }^{60}$ The assignment gives the assignee a complete and present right in the subject of the assignment and constitutes a contract between the assignor and the assignee. ${ }^{61}$ The early common law disallowed the assignment of a cause of action. ${ }^{62}$ Today, however, the general rule is that most causes of action can be assigned. ${ }^{63} \mathrm{In}$ the absence of a law of general assignability, LFCs would either not exist or exist on a much smaller scale than they do today.

\section{B. Maintenance}

Maintenance is the act of aiding the prosecution or defense of a lawsuit by a person or entity who is neither a party to the case nor who has a bona fide interest in the case. ${ }^{64}$ Maintenance is also described as "intermeddling" in a lawsuit by a third party who has no legal interest in the outcome of the case. ${ }^{65}$ The early common law prohibited maintenance on the primary ground that the civil litigation system should avail itself only to those persons who actually suffered an injury caused by the acts or omissubject.

59. See Appendix A to this article for a bibliography of scholarship and student comments on the

60. Artoc Bank \& Trust, Ltd. v. Apex Oil Co. (In re Apex Oil Co.), 975 F.2d 1365, 1369 (8th Cir. 1992); RESTATEMENT (SECOND) OF CONTRACTS § 317(1) (1981). (1981).

62. Sebok, supra note 14 , at 72 .

63. Id.

64. Martin, supra note 14, at 485; Sebok, supra note 14, at 72 .

65. Sebok, supra note 14, at 72-73. 
sions of others, and allowing strangers to participate in cases where they suffered no injury, undermined this principle. 66

Maintenance does not necessarily involve money. ${ }^{67}$ Helping a party in a lawsuit could come in the form of nothing more than moral support, encouragement, or simply "rooting" for one side or the other to prevail. ${ }^{68}$ In a 1929 decision by the New York Court of Appeals, Judge Cardozo wrote "maintenance inspired by charity or benevolence" should be distinguished from "maintenance for spite or envy or the promise or hope of gain." 69 The New York High Court considered the former type of maintenance lawful, but the latter type unlawful. ${ }^{70}$ The Court wrote, "It seems to be agreed that anyone may lawfully give money to a poor man to enable him to carry on his suit.... What is feared and forbidden is the oppressive intermeddling of wealth or officialdom for publicity or profit." 71 Today, some form of maintenance is permissible in twenty-eight states and the District of Columbia. ${ }^{72}$

\section{Champerty}

Champerty is a subcategory of maintenance. ${ }^{73}$ While maintenance need not involve the provision of money, champerty does. ${ }^{74}$ Champerty involves a non-party to a lawsuit providing money to a party litiganttypically the plaintiff - in exchange for part or all of the proceeds of the lawsuit. ${ }^{75}$ Sixteen states explicitly allow champerty. ${ }^{76}$

\footnotetext{
66. Martin, supra note 14, at 486-87; Sebok, supra note 14 , at 70, 94-99.

67. Sebok, supra note 14, at 100-02.

68. Id. at 101 .

69. In re Gilman's Adm'x, 167 N.E. 437, 439 (N.Y. 1929); Sebok, supra note 14, at 73.

70. Gilman's, 167 N.E. at 439-40; Sebok, supra note 14, at 73.

71. Gilman's, 167 N.E. at 439-40; See Sebok, supra note 14, at 73.

72. Sebok, supra note 14, at 98-99, 107-08. The states are Arizona, California, Colorado, Connecticut, Florida, Hawaii, Iowa, Kansas, Maine, Maryland, Massachusetts, Michigan, Missouri, Montana, New Hampshire, New Jersey, New York, North Carolina, North Dakota, Ohio, Oklahoma, Oregon, South Carolina, Tennessee, Texas, Washington, and West Virginia. Sebok, supra note 14, at 99 n.162 (citing cases and statutes for each state).

73. Martin, supra note 14, at 485; Sebok, supra note 14, at 68.

74. Martin, supra note 14, at 485; Sebok, supra note 14, at 68.

75. Martin, supra note 14, at 485; Sebok, supra note 14, at 68.

76. Martin, supra note 14, at 485-89; Sebok, supra note 14, at 107-08. The states are Colorado, Connecticut, Florida, Iowa, Kansas, Maine, Maryland, Massachusetts, Missouri, New Hampshire, North Carolina, Ohio, Oklahoma, Oregon, Washington, and West Virginia. Sebok, supra note 14, at 107 n. 190 (citing cases and statutes for each state).
} 


\section{Barratry}

Barratry is also a subcategory of maintenance, and like champerty, requires the provision of money to a party to a lawsuit in exchange for part of the proceeds of the suit. ${ }^{77}$ The person engaged in barratry, however, frequently provides funds to litigants. ${ }^{78}$ The Supreme Court of the United States described maintenance, champerty, and barratry this way: "Put simply, maintenance is helping another prosecute a suit; champerty is maintaining a suit in return for a financial interest in the outcome; and barratry is a continuing practice of maintenance or champerty."79 Eleven states prohibit barratry by statute. 80

Whether an LFC can operate in a state is a function of that state's law regarding assignment, maintenance, champerty, and barratry, and the approaches of the states vary considerably. ${ }^{81}$ The next part of this article discusses the legal status of LFCs in each state with respect to funding personal injury tort litigation.

\section{THE LEgAL StATUS IN EACH STATE OF THIRD PARTY FUNDING OF PERSONAL INJURY TORT LITIGATION}

\section{A. Twenty-nine states prohibit the assignment of personal injury claims and the proceeds of personal injury claims.}

Twenty-nine states and the District of Columbia prohibit the assignment of personal injury claims as well as the proceeds of personal injury claims. ${ }^{82}$ Under the laws of these thirty jurisdictions, an LFC cannot pro-

77. Martin, supra note 14, at 485-89; Sebok, supra note 14, at 72-73, 98.

78. Martin, supra note 14, at 485-89; Sebok, supra note 14, at 72-73, 98.

79. In re Primus, 436 U.S. 412, 424 n. 15 (1978); Sebok, supra note 14, at 73 n.43.

80. CAL. Penal Code $\S 158$ (West 2012); IdAHo Code ANN. § 18-1001 (West 2013); 720 ILl. Comp. Stat. AnN. 5/32-11 (West 2012); N.M. Stat. AnN. § 30-27-3 (West 2012); OKLA. Stat. tit. $21, \S 550$ (2012); 18 PA. Cons. STAT. ANN. $\$ 5109$ (West 2013); S.C. CodE ANN. § 16-17-10 (2011); Tex. Penal Code AnN. § 38.12 (2013); Vt. Stat. AnN. tit. 13, § 701 (West 2007); VA. Code AnN. $\S 18.2-452$ (West 2013); WASH. REV. CODE $\S 9.12 .010$ (2010); Martin, supra note 14, at 488.

81. Martin, supra note 14 , at 488-89.

82. Miller v. Jackson Hosp. \& Clinic, 776 So. 2d 122, 125 (Ala. 2000); Mat-Su Reg'l Med. Ctr., LLC v. Burkhead, 225 P.3d 1097, 1101-04 (Alaska 2010); Webb v. Gittlen, 174 P.3d 275, 276-78 (Ariz. 2008); Mallory v. Hartsfield, Almand \& Grisham, LLP, 86 S.W.3d 863, 866 (Ark. 2002); 21st Century Ins. Co. v. Super. Ct. of San Diego Cnty., 213 P.3d 972, 976 (Cal. 2009); Stearns \& Wheeler, LLC v. Kowalsky Bros., Inc., 955 A.2d 538, 542 (Conn. 2008); Barnes v. Quigley, 49 A.2d 467, 468 (D.C. 1946); Wachovia Ins. Servs., Inc. v. Toomey, 994 So. 2d 980, 988 (Fla. 2008); GA. CodE ANN. $\S 44-12-24$ (West 2012) (personal injury claims cannot be assigned); Villanueva v. First Am. Title Ins. Co., 740 S.E.2d 108, 110 (Ga. 2013); TMJ Haw. Inc. v. Nippon Trust Bank, 153 P.3d 444, 452-55 (Haw. 2007); Rinehart v. Farm Bureau Mut. Ins. Co. of Idaho, Inc., 524 P.2d 1343, 1344-46 (Idaho 1974); Kleinwort Benson N. Am., Inc. v. Quantum Fin. Servs., Inc., 692 N.E.2d 269, 274 (Ill. 1998); Midtown Chiropractic v. Ill. Farmers Ins. Co., 847 N.E.2d 942, 944-48 (Ind. 2006); Bolz v. State Farm 
vide funds for personal injury litigation because the assignment of personal injury claims as well as the proceeds of such claims is barred.

\section{B. Eight states prohibit the assignment of personal injury claims, but allow the assignment of the proceeds of personal injury claims.}

Eight states (Colorado; Maine; Maryland; Nebraska; Nevada; New York; North Carolina; and Virginia) also bar the assignment of personal injury claims, but allow the assignment of the proceeds of personal injury claims. ${ }^{83}$ The rationale for this distinction is that "although a personal injury claim is not assignable before judgment, an assignment of the proceeds of whatever recovery is had in such an action is enforceable, at least where the plaintiff retains control of the lawsuit without any interference from the assignee." 84 One court that adopted this view reasoned that allowing the assignment of a personal injury claim would result in a stranger to the law-

Mut. Auto. Ins. Co., 52 P.3d 898, 901 (Kan. 2002); Associated Ins. Serv., Inc. v. Garcia, 307 S.W.3d 58, 62-63 (Ky. 2010); Caro Props. (A), LLC v. City of Gretna, 3 So. 3d 29, 33-34 (La. App. 5 Cir. 2008); Gen. Exch. Ins. Corp. v. Driscoll, 52 N.E.2d 970, $972-73$ (Mass. 1944); Boogren v. St. Paul City Ry. Co., 106 N.W. 104, 105-06 (Minn. 1906); Freeman v. Berberich, 60 S.W.2d 393, 401 (Mo. 1933); Youngblood v. Am. States Ins. Co., 866 P.2d 203, 206-08 (Mont. 1993); Weller v. Jersey City, H \& P St. Ry. Co., 459, 460 (N.J. 1905); Quality Chiropractic, PC v. Farmers Ins. Co. of Ariz., 51 P.3d 1172, 1177-83 (N.M. Ct. App. 2002); W. Broad Chiropractic v. Am. Family Ins., 912 N.E.2d 1093, 1095-99 (Ohio 2009) ("A person may not assign the right to the future proceeds of a settlement if the right to the proceeds does not exist at the time of the assignment."). This language suggests that once a person has settled a personal injury claim, the right to the proceeds exists, and the person can then assign those proceeds. Aetna Cas. \& Sur. Co. v. Assocs. Transps., Inc., 512 P.2d 137, 139-41 (Okla. 1973); Sniderman v. Nerone, 9 A.2d 335, 336 (Pa. 1939); Hosp. Serv. Corp. of R.I. v. Pa. Ins. Co., 227 A.2d 105, 108-09 (R.I. 1967); A. Unruh Chiropractic Clinic v. De Smet Ins. Co. of S.D., 782 N.W.2d 367, 370-74 (S.D. 2010); Can Do, Inc., Pension \& Profit Sharing Plan \& Successor Plans v. Manier, Herod, Hollabaugh \& Smith, 922 S.W.2d 865, 867 (Tenn. 1996); State Farm Mut. Ins. Co. v. Farmers Ins. Exch., 450 P.2d 458, 459 (Utah 1969); Hereford v. Meek, 52 S.E.2d 740, 749-50 (W. Va. 1949).

83. Colo. Rev. Stat. ANN. §13-20-101 (West 2013) (All causes of action, except actions for slander or libel, survive the death of the plaintiff); Med. Lien Mgmt., Inc. v. Allstate Ins. Co., 2013 COA 88, ๆ $17-29$ (Colo. App. 2013) (the proceeds of a personal injury claim can be assigned because the claim survives the death of the plaintiff); Herzog v. Irace, 594 A.2d 1106, 1108-09 (Me. 1991) (the proceeds of a personal injury claim can be assigned); Averill v. Longfellow, 66 Me. 237, 238 (Me. 1876) (a personal injury claim cannot be assigned); MD. CODE ANN., CTS. \& JUD. PROC. § 6-401 (West 2013) (except for slander, tort claims survive the death of the plaintiff); Hernandez v. Suburban Hosp. Ass'n, Inc., 527 A.2d 144, 147-49 (Md. 1990) (the proceeds of claims that survive the death of the plaintiff can be assigned); Mut. of Omaha Bank v. Kassebaum, 814 N.W.2d 731, 735-37 (Neb. 2012) (the proceeds of a personal injury claim can be assigned, but the claim itself cannot); Achrem v. Expressway Plaza Ltd. P'ship, 917 P.2d 447, $448-49$ (Nev. 1996) (the proceeds of a personal injury claim can be assigned, but the claim itself cannot); N.Y. GEN. OBLIG. LAW § 13-101(1) (McKinney 2013) (a personal injury claim cannot be assigned); Williams v. Ingersoll, 89 N.Y. 508, 518-521 (1882) (the proceeds of a personal injury claim can be assigned); Charlotte-Mecklenburg Hosp. Auth. v. First of Ga. Ins. Co., 455 S.E.2d 655, 657 (N.C. 1995) (the proceeds of a personal injury claim can be assigned, but the claim itself cannot); VA. CODE ANN. $\S 8.01-26$ (West 2013) (the proceeds of a personal injury claim can be assigned, but the claim itself cannot); Dodd v. Lang, 71 Va. Cir. 235, 238 (Va. Cir. Ct. 2006).

84. Mut. of Omaha Bank v. Kassebaum, 814 N.W.2d 731, 735-37 (Neb. 2012) (citing 6 AM. JuR. 2D Assignments $\S 58$ at $188(2008))$. 
suit - the assignee - exerting control over the lawsuit, which would in turn promote champerty and violate public policy. ${ }^{85}$ An assignment of the proceeds, however, does not give the assignee the kind of control over the litigation that would give rise to concerns about champerty; therefore, the proceeds should be freely assignable. ${ }^{86}$ In these eight states, an LFC can advance money to personal injury plaintiffs because the plaintiffs have the lawful authority to assign their potential recoveries to the LFC.

\section{Nine states allow the assignment of personal injury claims and the pro- ceeds personal injury claims.}

Nine states (Delaware; Iowa; Michigan; Mississippi; New Hampshire; South Carolina; Texas; Washington; and Wyoming) allow the assignment of personal injury claims, and by definition, allow the assignment of the proceeds of such claims. ${ }^{87}$ The laws of these states give LFCs free reign to fund personal injury tort litigation.

\section{In four states the legality third party funding of personal injury tort litigation is an open question.}

In North Dakota, Oregon, Vermont, and Wisconsin, it is an open question whether LFCs can fund personal injury tort litigation. ${ }^{88}$

85. Charlotte-Mecklenburg Hosp. Auth. v. First of Ga. Ins. Co., 455 S.E.2d 655, 657 (N.C. 1995) (citing S. Ry. Co. v. O’Boyle Tank Lines, 318 S.E.2d 872 (N.C. 1984)).

86. Charlotte-Mecklenburg, 455 S.E.2d at 657.

87. DeL. CodE ANN. tit. 10, $\S 3704$ (West 2013) (personal injury actions survive the death of the plaintiff); St. Search Partners, L.P. v. Ricon Int'l, L.L.C., C.A. No. 04C-09-191-PLA, 2006 WL 1313859 , at *3 (Del. Super. Ct. May 12, 2006) (any claim that survives the death of the plaintiff can be assigned); Vimont v. Chicago \& N. W. Ry. Co., 21 N.W. 9, 10 (Iowa 1884) (a personal injury claim can be sold or transferred); MicH. COMP. LAWS ANN. §600.2921 (West 2013) (all actions and claims survive death); Grand Rapids \& I. Ry. Co. v. Cheboygan Cir. J., 126 N.W. 56, 60 (Mich. 1910) (a personal injury claim survives the death of the injured person, therefore, it can be assigned); Miss. CODE ANN. §11-7-7 (West 2013) (after a cause of action is commenced, it can be sold or assigned); Coleman Powermate, Inc. v. Rheem Mfg. Co., 880 So. 2d 329, 333 (Miss. 2004) (Mississippi law generally allows the assignment of personal injury claims); Dumas v. State Farm Mut. Auto. Ins. Co., 274 A.2d 781, 783 (N.H. 1971) (personal injury claims can be assigned); S.C. CODE ANN. § 15-5-90 (West 2013) (personal injury actions survive the death of the plaintiff); Doremus v. Atl. Coast Line R.R. Co., 130 S.E.2d 370, 379 (S.C. 1963) (any claim that survives the death of the plaintiff can be assigned); State Farm Fire \& Cas. Co. v. Gandy, 925 S.W.2d 696, 706-07 (Tex. 1996) (personal injury claims are assignable); WASH. REV. CODE $§ 4.20 .046$ (West 2013) (personal injury actions survive the death of the plaintiff); Kommavongsa v. Haskell, 67 P.3d 1068, 1072, 1078 (Wash. 2003) (any claim that survives the death of the plaintiff can be assigned); Winship v. Gem City Bone \& Joint, P.C., 185 P.3d 1252, 1257 (Wyo. 2008) (personal injury causes of action can be assigned).

88. Johnson v. Bergstrom, 587 P.2d 71, 73 (Or. 1978) (tort claims based on damage to property can be assigned; left open the question of whether personal injury claims can be assigned); see also Gregory v. Lovlien, 26 P.3d 180, 181-82 n.3 (Or. App. 2001) (same); In 1963, the Supreme Court of Wisconsin stated that "In Wisconsin, contrary to the rule in a majority of states[,] causes of action for personal injuries are assignable.” D’Angelo v. Cornell Paperboard Prods. Co., 120 N.W.2d 70, 73 (Wis. 
The laws of twenty-nine states and the District of Columbia do not permit LFCs to fund personal injury tort litigation. ${ }^{89}$ The laws of seventeen states do permit LFCs to fund personal injury tort litigation. ${ }^{90}$ It would be a mistake, however, to conclude that LFCs only do business in the seventeen states whose laws allow the assignment of personal injury claims, or the proceeds of personal injury claims, or both. LFCs do business in every state in the country. ${ }^{91}$ That would naturally lead one to ask: How can an LFC do business in a state whose law prohibits third party funding of tort litigation? The answer: There is a "choice of law" clause in the agreement between the LFC and the borrower. 92

A "choice of law" clause is a provision in a contract stating that the law of a chosen jurisdiction will govern a dispute between the parties. ${ }^{93} \mathrm{~A}$ typical choice of law clause might say, "This Agreement shall be governed, construed, and enforced in accordance with the laws of the State of [insert state] without regard to its choice of law principles." In order for LFCs to do business in the thirty jurisdictions whose laws prohibit the assignment of personal injury claims and the proceeds of personal injury claims, the LFCs include a choice of law clause in their funding agreements, selecting a state that does allow the assignment of the claim itself, the proceeds of the claim, or both. The publicly disclosed members of ALFA choose New York as their choice of law jurisdiction because New York case law allows the assignment of the proceeds of personal injury claims even though New York

1963 ) (citing what is now WIS. STAT. ANN. § 895.01 (West 2013)). The Court reaffirmed this principle in 1967. Associated Hosp. Serv., Inc. v. Milwaukee Auto. Mut. Ins. Co., 147 N.W.2d 225, 226 n.3 (Wis. 1967) (the assignment of personal injury claims is permitted in Wisconsin). In 2006, however, the Court retreated from D'Angelo and Associated Hosp. Serv., Inc. and limited the assignability of personal injury claims to those cases involving insurance subrogation. Yorgan v. Durkin, 715 N.W.2d 160, 163-64 (Wis. 2006). The Court did not reach the issue of the assignability of tort claims because neither the state trial court, the state intermediate appellate court, nor the parties raised or addressed the matter. Id. Under Yorgan, it is an open question whether Wisconsin law allows the assignment of tort claims. Id.

89. See supra Part III.A.

90. See supra Parts III.B, III.C.

91. ALFA: Setting the Industry Standard, http://www.americanlegalfin.com/AboutLegal Funding.asp (last visited September 16, 2013).

92. The author has on file a funding agreement from Whitehaven S.F. LLC, a Manhattan, New York based LFC. Paragraph 26 of the agreement is a choice of law clause and says, "[The] Plaintiff acknowledges and agrees that the laws of the State of New York shall control the interpretation of this agreement and all terms, conditions, relationships[,] and duties of the parties." Whitehaven is one of the nine LFC signatories to the February 17, 2005 Assurance of Discontinuance with the Attorney General of the State of New York. See N.Y. Assurance of Discontinuance, supra note 20, at 1-2.

93. John R. Leathers, Choice of Law in Kentucky, 87 KY. L.J. 583, 599 (1999). Choice of law clauses are not the same as "choice of forum" clauses. Id. Choice of forum clauses select a particular state as the forum for litigation of any disputes that may arise between the parties. Id. at 597-98. The main difference between the two being the law chosen by the parties in a choice of law clause will apply no matter where any litigation between the parties takes place. Id. at 597-99. The place where any litigation will take place is the subject of a choice of forum clause. Id. 
statutory law prohibits the assignment of personal injury claims themselves. ${ }^{94}$

A carefully drafted choice of law clause could allow an LFC to avoid an individual state's prohibition on the assignment of personal injury claims or the proceeds of such claims. And with the exception of New York, Maine, Ohio, and Nebraska, there is no governmental oversight of LFCs. ${ }^{95}$ This article will now analyze the regulatory regimes in those states.

\section{The Regulatory Regimes IN NEW YoRK, MAINE, OHIO, AND NEBRASKA}

On February 17, 2005, the Attorney General of the State of New York and nine New York based LFCs entered into an "Assurance of Discontinuance" agreement that resulted from negotiations between the Attorney General and the LFCs. ${ }^{96}$ The main purpose of the "Assurance" was to put into place certain disclosure requirements that LFCs would have to provide to all borrowers in the State of New York. ${ }^{97}$ The Attorney General insisted on the disclosures because prior to the execution of the Assurance, he was concerned that LFCs were taking unfair advantage of New York consumers. ${ }^{98}$ In 2007, the State of Maine enacted "The Maine Consumer Credit Code Legal Funding Practices" for similar reasons. ${ }^{99}$ The State of Ohio enacted an LFC mandatory disclosure law in 2008, and in 2010, Nebraska enacted the "Nonrecourse Civil Litigation Act."100 The Assurance and the state legislation are worth a closer examination.

94. N.Y. GEN. OBLIG. LAW § 13-101(1) (McKinney 2013) (a personal injury claim cannot be assigned); Williams v. Ingersoll, 89 N.Y. 508, 518-521 (1882) (the proceeds of a personal injury claim can be assigned).

95. See supra notes 16-19.

96. See N.Y. Assurance of Discontinuance, supra note 20. The Nine LFCs who signed off on the agreement are: Plaintiff Support Services, Inc.; Pre-Settlement Finance, LLC; QuickCash, Inc.; Magnolia Funding, LLC; BridgeFunds Limited; Plaintiff Funding Corporation d/b/a LawCash; Oasis Legal Finance Co., LLC; The Whitehaven Group, LLC; and New Amsterdam Capital Partners LLC d/b/a LawMax. Id. at 1-2.

97. Id. at 3

98. Id.

99. The Maine Consumer Credit Code Legal Funding Practices. ME. Rev. StAT. tit. 9-A, §§ 12101 to -107 (2012).

100. Ohio Rev. Code AnN. $§ 1349.55$ (West 2012); The Nonrecourse Civil Litigation Act, NeB. REV. STAT. ANN. §§ 25-3301 to -3309 (West 2013). 


\section{A. New York}

As LFCs began to proliferate in the State of New York, they drew the attention of Eliot Spitzer, the Attorney General of the State of New York. ${ }^{101}$ General Spitzer conducted an investigation and made a number of findings with respect to nine LFCs. ${ }^{102}$ First, each of the nine LFCs maintained membership in ALFA and provided cash advances to consumers with pending personal injury claims or causes of action. ${ }^{103}$ Second, each advertised in New York in English and Spanish, but some LFCs' borrowers spoke Spanish as their primary language and lacked fluency in English. ${ }^{104}$ Third, the LFCs typically advanced between $\$ 1,000$ and $\$ 7,500$ in exchange for amounts significantly in excess of what they advanced to borrowers. ${ }^{105}$ Fourth, prior to advancing funds, LFCs obtained permission from the borrower to contact the borrower's attorney in order to review the claim or cause of action. ${ }^{106}$ Sixth, if the LFC agreed to advance funds to the borrower, she had to agree to grant the LFC a lien on the proceeds of any settlement, judgment, or verdict up to the agreed upon repayment amount. 107 And seventh, if the borrower did not receive any proceeds from her claim or cause of action, she did not have to repay the LFC. 108

As of February 17, 2005, General Spitzer determined that nine LFCs had entered into thousands of transactions with consumers in the State of New York. ${ }^{109}$ His findings caused him to believe that consumers might not have been making reasoned decisions to engage LFCs because they might not have adequately understood the terms of their agreements with the LFCs. ${ }^{110} \mathrm{He}$ further opined that LFC practices in New York may have violated state law in five specific respects. ${ }^{111}$

First, the LFCs' agreements did not adequately disclose the following: (a) the annualized percentage rate of return; (b) the degree to which a borrower's total cost could vary depending on the length of time it took to repay the advance; (c) the actual dollar amount the borrower would repay if she made payments at specified intervals, such as every six months; (d) the

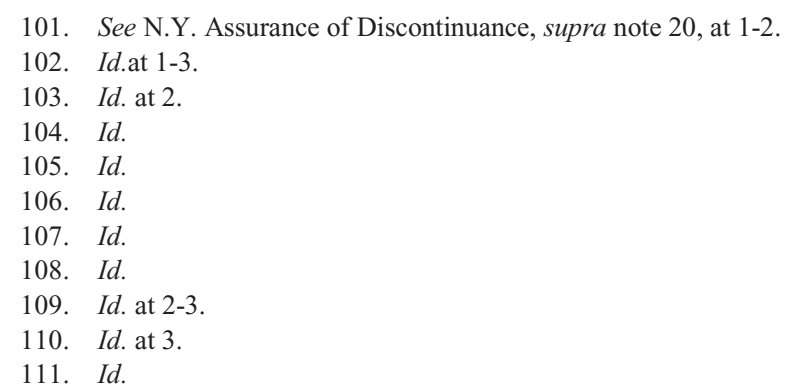


actual dollar amount the borrower would pay in fees; and (e) the minimum payment amount. ${ }^{112}$

Second, the LFC agreements were multiple pages in length and written in language that would be inscrutable to a reasonable borrower. ${ }^{113}$ Third, not all of the LFCs provided agreements in the native language of borrowers who lacked fluency in English. ${ }^{114}$ Fourth, the agreements did not provide the borrower with a penalty free cancellation option that could be exercised within a reasonable time after contract execution. ${ }^{115}$ And sixth, some LFC agreements did not require a written confirmation from the borrower's attorney that the attorney explained the terms of the agreement to the borrower. 116

In order to resolve General Spitzer's concerns, the LFCs agreed to enter into an "Assurance of Discontinuance" with the Attorney General.117 The LFCs did not admit to any wrongdoing. ${ }^{118}$ The Assurance imposed nine requirements on the LFC signatories for all transactions with New York consumers executed on or after May 18, 2005.119

First, all LFC agreements have to be in writing, and the writing must be clear, coherent, and use words with common and every day meanings. 120

Second, each agreement must include a "Disclosure Statement" on the first page that is written in at least twelve point bold type and informs the borrower of the following: (a) the total amount being advanced; (b) an itemization of one time fees broken out item by item (e.g., application, processing, attorney review, broker, etc.); (c) the annual percentage interest rate charged and how often interest compounds; and (d) the total amount the borrower will repay broken out by six month intervals and carried for-

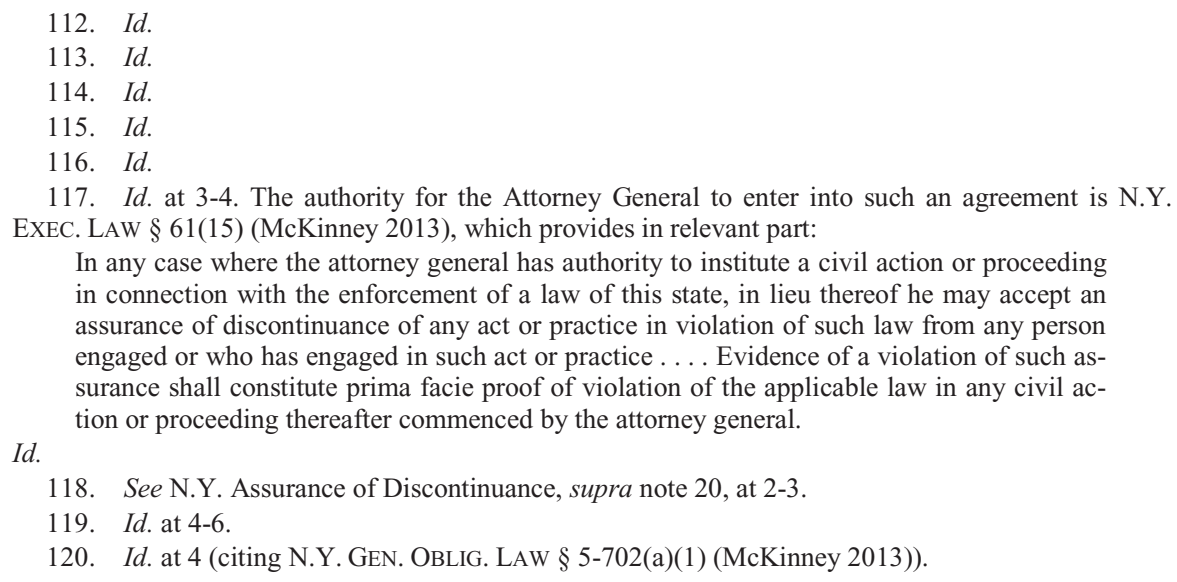


ward to thirty-six months, including all fees and the minimum payment amount. 121 The Assurance included the following sample Disclosure Statement: 122

\section{Disclosure Statement}

Total amount to be advanced to consumer under this contract: $\$$

Itemized Fees:

application $\$$

processing \$

attorney review $\$$

broker \$

other \$

Total fees: $\$$

Annual percentage fee (rate of return)

on advance, compounded monthly: $\%$

Total amount to be repaid by consumer

if at 6 months:
if at 12 months:
if at 18 months:
if at 24 months:
if at 36 months:

Third, the LFC agreement must provide the consumer with a five business day period to cancel the contract without suffering a penalty. 123 The cancellation language has to be written as follows:

New York Consumer's Right To Cancellation: You May Cancel This Contract Without Penalty Or Further Obligation Within Five Business Days From The Date You Receive Funding From [Name of LFC]. ${ }^{124}$

Additionally, the agreement has to state that in order for the cancellation to be effective, the borrower must either: (a) return the full amount advanced by the LFC to the LFC by personally delivering the LFC's uncashed check to the LFC's office within five business days of the disbursement of the funds; or (b) mail a notice of cancellation that includes the full amount advanced by the LFC in the form of the LFC's check, a registered check, a certified check, or a money order, by insured, registered, or certified United States mail, postmarked within five business days of re- 
ceiving the LFC's advance, at the address specified in the contract for receipt of cancellation notices. ${ }^{125}$

Fourth, the borrower must initial each page of the contract. ${ }^{126}$

Fifth, the agreement must contain a legend immediately above the borrower's signature in at least twelve-point bold typeface that says:

Do Not Sign This Contract Before You Read It Completely Or If It

Contains Any Blank Space. Before You Sign This Contract You Should Obtain The Advice Of Your Attorney. You Are Entitled To

A Completely Filled In Copy of This Contract. ${ }^{127}$

Sixth, the borrower's attorney must execute a written certification stating that she has reviewed the agreement and explained its terms to the borrower, including the annual percentage rate applied to the advance. ${ }^{128}$

Seventh, the agreement must be written in the same language used during oral negotiations between the LFC and the borrower. ${ }^{129}$ If the borrower's primary language is neither English nor Spanish, the "principal terms" of the contract have to be translated into writing in the borrower's native language; the borrower has to sign the translated document and initial each page; and the translator has to sign a notarized statement confirming that the "principal terms" have been presented to the borrower in her primary language and that the borrower acknowledged as much. ${ }^{130}$ The Assurance defines "principal terms" as everything in the "Disclosure Statement" and the legend above the borrower's signature advising her not to sign the agreement before reading it and advising her to consult with an attorney. ${ }^{131}$

Eighth, if the agreement has a fee shifting provision that gets triggered in a breach of contract action, it must state that attorneys' fees and costs may be recoverable by the prevailing party and any such fees and costs must be reasonable. ${ }^{132}$

The ninth and final requirement in the Assurance is that LFCs cannot require that a borrower submit any dispute she has with the LFC to arbitration. 133

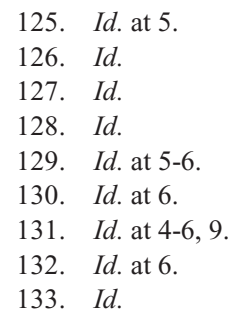


The Assurance does not impose an upper limit on how much the LFCs can charge borrowers in interest, fees, or other costs, thus it does nothing to address what many find most objectionable about third party litigation funding: exorbitant interest charges. ${ }^{134}$ As of this writing, the New York Legislature has not enacted anything to regulate LFCs, thus the Assurance represents the Empire State's sole regulatory regime with respect to LFCs.

\section{B. Maine}

LFCs did not want what happened in New York to be repeated in the rest of the country, so in 2008, ALFA began lobbying state legislatures to either leave LFCs alone or enact legislation that would be friendly to the industry, i.e., laws that do not impose limits on interest LFCs can charge borrowers. ${ }^{135}$ In 2007, Maine enacted "The Maine Consumer Credit Code Legal Funding Practices." 136 ALFA actively participated in the passage of the law. ${ }^{137}$

Maine's law defines "legal funding" as "a transaction in which a company makes a cash payment to a consumer in exchange for the right to receive an amount out of the potential proceeds of any realized settlement, judgment, award, or verdict the consumer may receive in a civil claim or action." 138 The law goes on to say that if the consumer does not recover any proceeds from her claim, she is not required to repay the LFC. 139

The law explicitly excludes "legal funding" from Maine's definition of a "consumer credit transaction" or "supervised loan." 140 The mandatory disclosures Maine's law requires are substantially similar to the disclosures required by the Assurance. ${ }^{141}$ For example, the funding agreements have to be in writing, and the writing must be in plain language; the disclosure statement is similar to the disclosure statement mandated by the Assurance except the annual percentage rate in Maine is compounded semiannually rather than monthly, and the total amount the borrower will repay is broken out by six month intervals and carried forward forty-two months rather than

134. Echeverria v. Estate of Linder, No. 018666/2002, 2005 WL 1083704, at *4 (N.Y. Sup. Ct. Mar. 2, 2005); McLaughlin, supra note 29, at 655-57; Beydler, supra note 16, at 1181-86; Estevao, supra note 4, at 492-96.

135. Appelbaum, supra note 12; see AFLA, supra note 41.

136. See note 99, supra. The law took effect on January 1, 2008. ME. REV. STAT. tit. 9-A, § 12-101 (2012).

137. Appelbaum, supra note 12; see AFLA, supra note 41.

138. ME. Rev. StAT. tit. 9-A, § 12-102(2) (2012).

139. Id.

140. $\S 12-103(2),(3)$

141. § 12-104; see supra Part IV.A. 
thirty-six. ${ }^{142}$ The five-business day cancellation provision is the same as what the Assurance requires as well as the mandate that the borrower initial each page of the agreement. ${ }^{143}$

Maine's law also requires the same legend above the borrower's signature that the Assurance requires, which advises the borrower not to sign the agreement before reading it and advises her to consult with an attorney. ${ }^{144}$ Maine's law, however, requires two additional "legends" that must appear above the borrower's signature in twelve point bold type. ${ }^{145}$

One must say:

Notice: Legal Funding Providers Must Register With Maine Regulators. Go To www.maine.gov/pfr/consumercredit And Select The "Rosters" Link To Verify A Litigation Funding Provider's Registration Or To Contact Providers To Obtain Comparative Rate Quotes. ${ }^{146}$

The other must say:

The Litigation Funding Provider Agrees That It Has No Right to And Will Not Make Any Decisions With Respect To The Conduct Of The Underlying Civil Action Or Claim Or Any Settlement Or Resolution Thereof And That The Right To Make Such Decisions Remains Solely With The Consumer And The Consumer's Attorney. ${ }^{147}$

Maine's law bars LFCs from requiring borrowers to submit disputes to arbitration, and requires that LFC agreements contain a written acknowledgment by the borrower's attorney stating: (1) that she has reviewed the contract, all costs and fees have been disclosed, including the amount to be paid by the borrower; (2) the attorney is being paid pursuant to a written fee agreement; (3) all proceeds from the claim or lawsuit will be distributed from the attorney's trust account; and (4) the attorney is following the written instructions of the borrower with respect to the LFC advance. ${ }^{148}$ Maine requires the same language translation for non-English speaking borrowers

142. § 12-104(2); see supra Part IV.A. Maine does not allow an LFC to assess fees for any period exceeding forty-two months from the date of contract execution. $\S 12-105(1)$. The law also authorizes fees to be compounded semiannually, but not for any lesser time period. $\S 12-105(2)$. In calculating the annual percentage rate, the LFC must include all charges directly or indirectly payable by the borrower, and the rate must be computed based only on amounts actually received and retained by the borrower. $\S 12-105(3)$.

143. § 12-104(3), (4); see supra Part IV.A.

144. $§ 12-104(6)$; see supra Part IV.A.

145. $\S 12-104(5),(7)$.

146. $\S 12-104(5)$. An LFC cannot do business in Maine without first registering with the proper state official. 9-A, § 12-106(1).

147. $\S 12-104(7)$.

148. $§ 12-104(8),(9)$. 
that the Assurance requires, and requires the same provision regarding fee shifting in the event of litigation between the LFC and the borrower. 149

\section{Ohio}

In 2008, Ohio enacted a one-statute act to regulate LFCs. ${ }^{150}$ ALFA also participated in this law's passage. ${ }^{151}$ Ohio's law requires far less in terms of disclosure than what the Assurance and Maine require. ${ }^{152}$ The Buckeye State only requires that the following be disclosed in LFC agreements: (1) the total amount advanced; (2) an itemization of one time fees; (3) the total to be repaid by the borrower in six month intervals for thirtysix months, including all fees; and (4) the annual percentage rate, calculated as of the last day of each six month interval, including the frequency of compounding. ${ }^{153}$ Ohio does require the same cancellation provision as the Assurance and Maine, and like Maine, requires a "non-interference" clause. ${ }^{154}$ Ohio borrowers have to initial each page of the agreement, and have to be advised not to sign the contract without reading it in its entirety and to consult with an attorney. ${ }^{155}$

Additionally, Ohio's law requires that borrowers be advised to consult with a "tax, public, or private benefit planning or financial professional," and requires that the borrower acknowledge that her attorney has not provided "tax, public or private benefit planning or financial advice" with respect to the LFC advance. ${ }^{156}$ The law requires the borrower's attorney to execute a written acknowledgment stating: (1) that she has reviewed the contract, all costs and fees have been disclosed, including the annual percentage rate applied to calculate how much the borrower has to repay; (2) the attorney is being paid pursuant to a written contingency fee agreement; (3) all proceeds from the claim or lawsuit will be distributed from the attorney's trust account; and (4) the attorney is following the written instructions of the borrower with respect to the LFC advance. ${ }^{157}$

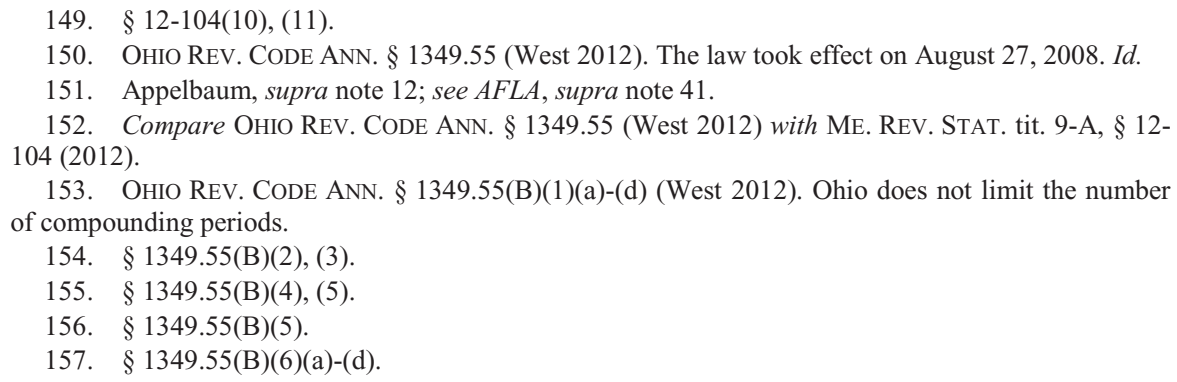


Last, Ohio's law requires the same language translation for nonEnglish speaking borrowers that the Assurance and Maine require, but it does not have a fee shifting provision, a "no mandatory arbitration" provision, or a registration requirement. ${ }^{158}$

\section{Nebraska}

In 2010, Nebraska enacted the "Nonrecourse Civil Litigation Act."159 Nebraska's mandatory disclosure statement is the same as Ohio's, except Nebraska's requires LFCs to disclose the total amount in broker fees involved in the transaction while Ohio's does not. ${ }^{160}$ Nebraska's fivebusiness day cancellation clause is the same as the Assurance's, Maine's and Ohio's. ${ }^{161}$ Also, like Maine and Ohio, Nebraska requires LFC agreements to include a "no interference clause," i.e., a statement that the LFC does not have the right to make any decisions regarding the underlying lawsuit. 162 Nebraska differs from Maine and Ohio in that the Cornhusker State requires borrowers to execute a written acknowledgment stating that they have reviewed the LFC agreement in its entirety. ${ }^{163}$ Nebraska does not, however, require the borrower to initial each page of the contract. 164

Nebraska requires a written attorney acknowledgement that mirrors Maine's and Ohio's, except Nebraska requires two additional acknowledgments by the attorney for the borrower: one stating that the attorney cannot be paid commissions or referral fees by the LFC; and one stating whether the attorney does or does not have a financial interest in the LFC. ${ }^{165}$ Nebraska differs from Main and Ohio in another respect; the State requires a disclosure "in a box with bold fifteen-point font stating the following in capitalized letters:"

IF THERE IS NO RECOVERY OF ANY MONEY FROM YOUR LEGAL CLAIM OR IF THERE IS NOT ENOUGH MONEY TO PAY THE CIVIL LITIGATION FUNDING COMPANY BACK IN FULL, YOU WILL NOT OWE THE CIVIL LITIGATION FUNDING COMPANY ANYTHING IN EXCESS OF YOUR

158. $\S 1349.55(\mathrm{~B})(7) ; \S 1349.55(\mathrm{C})$.

159. NeB. Rev. Stat. ANN. $\S \S 25-3301$ to -3309 (West 2013). The law took effect on July 15, 2010. Id.

160. Compare Neb. Rev. Stat. Ann. § 25-3303(1)(a)(i)-(v) (West 2013) with Ohio Rev. Code ANN. § 1349.55(B)(1)(a)-(d) (West 2012).

161. Neb. Rev. Stat. ANN. § 25-3303(1)(b) (West 2013).

162. $\S 25-3303(1)(\mathrm{c})$.

163. $\S 25-3303(1)(\mathrm{d})$

164. Compare NeB. Rev. Stat. AnN. § 25-3303(1)(d) (West 2013) with Me. Rev. Stat. tit. 9-A, $\S 12-104(4)$ (2012) and OHIO REV. CODE ANN. § 1349.55(B)(4) (West 2012).

165. NeB. ReV. StAT. ANN. § 25-3303(1)(f)(i)-(vi) (West 2013). 


\section{RECOVERY UNLESS YOU HAVE VIOLATED THIS} PURCHASE AGREEMENT. 166

This makes Nebraska the only state to prohibit an LFC from requiring repayment in those instances where the borrower recovers less than what she owes the LFC. ${ }^{167}$ Like Ohio, Nebraska's law does not have a fee shifting provision or a "no mandatory arbitration" provision. It also lacks a language translation provision for persons not fluent in English. The law bars LFCs from paying or offering to pay commissions or referral fees to lawyers representing borrowers, and it also bars LFCs from accepting commissions or referral fees from lawyers representing borrowers. ${ }^{168}$ Also, an LFC cannot "knowingly" advance money to a borrower who has already assigned the proceeds of her claim to another LFC, unless the second LFC buys out the first LFC's "entire accrued balance."169 There is a loophole, however, in that the two LFCs and the borrower can agree in writing to the second LFC advancing funds to the borrower without the second LFC having to buy out the first. ${ }^{170}$ This creates a scenario where the borrower would owe multiple LFCs, and the statute does not specify which LFC gets paid first when the duty to repay is triggered.

Similar to Maine, Nebraska's law prohibits LFCs from assessing fees for any period beyond thirty-six months from the date of contract execution; it authorizes LFCs to compound fees semiannually but not for a lesser time period; it requires the computation of the annual percentage rate to include all direct and indirect charges the borrower has to pay; and it requires the computation of the annual percentage rate to be based only on monies actually received by the borrower. ${ }^{171}$ In addition to a mandated "non-interference with the underlying litigation" clause, Nebraska's law states that no communication between the LFC and the borrower's attorney limits, waives, or abrogates the attorney-client privilege or the work product doctrine. ${ }^{172}$ Neither Maine nor Ohio has a similar law protecting the attorney client privilege. Finally, like Maine, Nebraska requires that LFCs register in the state as a prerequisite to conducting business in the state. ${ }^{173}$

As one can see, there are a number of similarities in the regulatory efforts of New York, Maine, Ohio, and Nebraska. There are also some signif-

166. $§ 25-3303(1)(\mathrm{g})$.

167. Appelbaum, supra note 11 (a woman won $\$ 169,125$ in a personal injury suit, but owed an LFC \$221,000).

168. NeB. ReV. Stat. ANN. § 25-3304(1), (2) (West 2012).

169. § 25-3304(4).

170. Id.

171. § 25-3305(1)-(3).

172. $\S 25-3306$.

173. $§ 25-3307(1)$. 
icant differences. Ohio's law consists of a single statute that requires considerably fewer disclosures than Maine's and Nebraska's, which suggests that ALFA was most effective in its lobbying efforts in the Buckeye State. ${ }^{174}$ What little state legislation exists regarding LFCs has only existed since January 1, 2008 when Maine enacted its law. ${ }^{175}$ Outside of New York, Maine, Ohio, and Nebraska, LFCs have free reign to do almost anything they want, including executing agreements without disclosing the annual percentage rate, the minimum payment amount, or how much it would cost a borrower to repay the advance at certain time intervals. This is crucial information a borrower must and should know before applying for and accepting a loan. The other forty-six states may or may not enact LFC regulations. This means that citizens in $92 \%$ of the states in this country are left to their own devices when it comes to dealing with LFCs. The typical personal injury tort victim is no match for the typical LFC when it comes to knowledge of finance, interest rates, risk, and the like. A national regulatory regime is necessary, and that is what this article will discuss next.

\section{The Consumer Financial Protection Bureau, the Federal TRADE COMMISSION, OR BOTH SHOULD REgulate LFCS}

This is not the first article to call for the regulation of LFCs. ${ }^{176}$ It may, however, be the second to call for the regulation to occur at the national level rather than at the state level. ${ }^{177}$ Professor Arthur E. Wilmarth, Jr. has opined that the Consumer Financial Protection Bureau ("CFPB") would be an apt regulator of LFC contracts. ${ }^{178}$ The CFPB could regulate LFCs if the contracts LFCs executed with borrowers could be deemed "financial products or services provided to consumers" under the Consumer Financial Protection Act of 2010 ("CFPA"). ${ }^{179}$ A "consumer" under the CFPA is "an individual or an agent, trustee, or representative acting on behalf of an individual." 180 A "financial product or service" under the CFPA is a transac-

174. Appelbaum, supra note 12; see AFLA, supra note 41.

175. ME. Rev. StAT. tit. 9-A, § 12-101 (2012). Ohio's law took effect on August 27, 2008, and Nebraska's took effect on July 15, 2010. OHIO Rev. CodE ANN. § 1349.55 (West 2012); Neb. Rev. STAT. ANN. § 25-3301 (West 2013).

176. See, e.g., Hashway, supra note 4, at 785-90; Shaltiel \& Cofresi, supra note 16, at 349-56; $356-61$.

177. Arthur E. Wilmarth, Jr., The Desirability of a Uniform Federal-State Regulatory Regime for Alternative Litigation Funding Contracts for Consumers, http://www.law.gwu.edu/News/20112012 events/Documents/Wilmarth\%20Submission.pdf (last visited Oct. 15, 2013).

178. The CFPB derives its regulatory authority from the Consumer Financial Protection Act of 2010. Wilmarth, supra note 177, at n. 1 (citing Title X of the Dodd-Frank Wall Street Reform and Consumer Protection Act, Pub. L. No. 111-203, 124 Stat. 1376, 1955).

179. Wilmarth, supra note 177, at 1.

180. Id. at $1 \mathrm{n} .2$ (citing 12 U.S.C. § 5481(4)). 
tion that "extends credit to consumers and provides financial advisory services to consumers on individual financial products or services, including services assisting consumers with debt management."181

CFPB regulation of LFCs could entail rules, regulations, or both that require LFCs to provide consumers "timely information" in a format that is "understandable" and that enables consumers to make responsible borrowing decisions. 182 Those rules and regulations could also empower the CFPB to protect consumers from discrimination as well as "unfair, deceptive, or abusive acts and practices." 183 This authority could include the ability to conduct investigations and initiate enforcement actions to prevent LFCs from engaging in "unfair, deceptive, or abusive acts and practices." 184

The Federal Trade Commission ("FTC") seems like another natural fit as a regulator of LFCs given its role as the primary enforcer of the Truth in Lending Act ("TILA"). 185 The purpose of TILA is to "enhance economic stabilization and competition among financial institutions by requiring the meaningful disclosure of credit terms to consumers." 186 LFCs are not covered by TILA, however, because they are not "creditors" for the purpose of TILA. ${ }^{187}$ A "creditor" under TILA is one who regularly extends credit to consumers; "credit" means the deferred payment of a "debt"; and a "debt" is an obligation to repay money that is not contingent upon a future event. ${ }^{188}$ Because LFCs condition a borrower's duty to repay on the borrower actually recovering something from her claim or lawsuit, the monies LFCs advance to borrowers is not a "debt" for the purposes of TILA because the event triggering the duty to repay may not materialize. ${ }^{189}$ In order for the FTC to regulate LFCs, the definition of "debt" would have to be amended in TILA to include obligations to repay that are triggered by a contingent event. 190

Assuming the CFPB, the FTC, or both could regulate LFC's, what form would the regulations take? Jenna Wims Hashway, Yifat Shaltiel, and

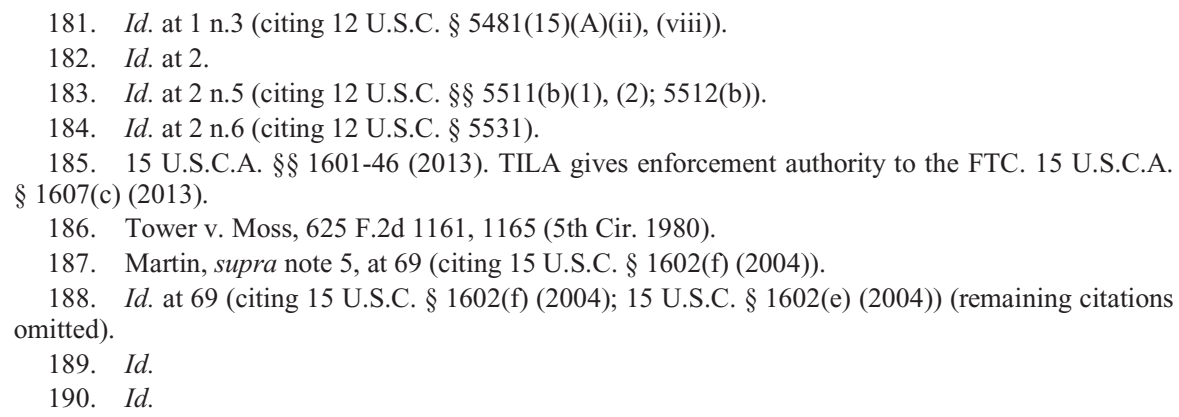


John Cofresi have actually drafted model legislation, although it is geared toward state legislatures rather than any federal agency. ${ }^{191}$ What Hashway, Shaltiel, and Cofresi have proposed is thoughtful and impressive. This author differs with them in who the regulator should be.

The February 17, 2005 Assurance between nine New York LFCs and the Attorney General of the State of New York contains some good, consumer-oriented disclosure provisions and seems like a good place to start in terms of model legislation. All of the provisions in the Assurance should be included in model national legislation, and there are several that should be added. 192

There should be a provision requiring LFCs to register in each state where they do business, and pre-registration should be a condition of doing business in the state. Mandatory registration will help identify just how many LFCs there are and provide a means to identify those LFCs that engage in the type of misconduct that would warrant an enforcement action. To that end, all LFC contracts should contain language advising borrowers to verify the registration of an LFC before conducting a transaction with it. All the contracts should have a "no interference" clause making it clear to borrowers that an LFC has no right to decide how a case is to proceed or on what terms it is to be settled, if at all. LFC's should also be prohibited from requiring borrowers to submit disputes to arbitration. An LFC contract should be unenforceable if it is not accompanied by a signed acknowledgment from the borrower's attorney stating that the attorney has explained all of the provisions of the contract to the borrower, including how much it is going to cost the borrower to accept the advance from the LFC.

LFCs should not be allowed to assess fees for any period exceeding thirty-six months from the date of contract execution, and fees assessed by LFCs should be allowed to compound semiannually, but not for a lesser time period. The annual percentage rate must be disclosed and how it is calculated should be explained in plain language. That calculation should include all charges the borrower is expected to pay, and must be based only on monies the borrower actually receives and retains from the LFC. Attorneys representing borrowers should not be allowed to accept compensation from an LFC for referring a client to the LFC. Moreover, attorneys should be required to disclose whether they have a financial interest in the LFC.

191. Hashway, supra note 4, at 785-90; Shaltiel \& Cofresi, supra note 16, at 349-61.

192. Attached, as Appendix B, is a proposed "Nonrecourse Civil Litigation Transaction Reform Act." It is a combination of the See N.Y. Assurance of Discontinuance, supra note 20; The Maine Consumer Credit Code Legal Funding Practices. Me. Rev. Stat. tit. 9-A, §§ 12-101 to -107 (2012); Ohio Rev. Code Ann. § 1349.55 (West 2012); and The Nonrecourse Civil Litigation Act, Neb. Rev. Stat. Ann. $\S \S 25-3301$ to -3309 (West 2013). 
To that same end, LFCs should be barred from accepting compensation from attorneys.

Each contract should contain a provision informing the borrower that the duty to repay is contingent upon the borrower recovering something from her claim or lawsuit, and if she recovers nothing or recovers less than what she borrowed from the LFC, she does not have to repay the LFC. Each contract should state that any communication between the attorney and the LFC does not constitute a waiver, abrogation, or limitation on the attorney-client privilege or the work product doctrine.

The author has on file a funding agreement from Whitehaven S.F. LLC, a Manhattan, New York based LFC. That agreement contains two clauses that should appear in every LFC agreement. The first says:

[The] Plaintiff has been advised and instructed by Whitehaven S.F. LLC that [he or she] should seek this funding from sources other than Whitehaven S.F. LLC, including but not limited to banks, credit cards, family, friends, etc.

The second says:

[The] Plaintiff has been advised by Whitehaven S.F. LLC that Whitehaven S.F. LLC is a provider of funds of last resort and that other sources of funds, financing, or both, if available, would likely be less expensive.

On the other hand, the Whitehaven S.F. LLC funding agreement has a provision that should be banned in all LFC contracts, and it says, "[The] Plaintiff hereby waives any defenses to payment of this amount, and hereby agrees not to seek to avoid payment of this amount." If there is a legitimate and lawful defense a borrower can raise in a dispute with an LFC, the borrower should be able to raise it, and should not preemptively waive it.

In sum, national legislation should consist of everything in the Assurance, plus the most consumer-friendly provisions in Maine's and Nebraska's laws, plus the two additional "caveat emptor" clauses in the Whitehaven agreement. Such legislation should not include an interest rate cap. The absence of interest rate caps is the main source of controversy surrounding LFCs, and the interest rates most LFCs charge are exorbitant and usurious. So why not propose legislation that includes a rate cap? In 2008, Professor Susan Lorde Martin answered that question eloquently and persuasively:

Government should not be so paternalistically protective of people who do not have access to traditional forms of credit that it keeps those people from owning homes, having washers and dryers or pursuing meritorious lawsuits. More widely available credit creates important opportunities for those with a poor credit history or without any credit history at all. Thus, legislatures and courts must recognize that subprime 
credit is going to be more expensive, because the risks are greater for the lender, and not seek, because of sympathy for subprime borrowers, to compare subprime rates with those of traditional lenders. Doing so will discourage litigation funders, decreasing competition and opportunities instead of expanding them, and forcing plaintiffs with no resources to accept unfairly low settlement offers because they cannot afford to wait for a better offer or to go to trial. ${ }^{193}$

\section{CONCLUSION}

When parties to a transaction enter into it freely and fully informed, the likelihood that one party can or will take unfair advantage of the other is reduced. Currently, in forty-six states and the District of Columbia, LFCs have no duty to disclose some of the most basic facts that an ordinary borrower needs to know in order to make an informed decision about whether to borrow money or not. This is untenable and an invitation to LFCs to exploit unwary consumers. LFCs should be regulated at the national level so that consumers in every state will enjoy the same core level of protection, and every LFC in the country will have to abide by the same core set of rules and regulations. The regulatory regime proposed in this article will not solve every ill that accompanies third party financing of litigation, but at least it gives potential borrowers more information and disclosures than those in forty-six states and the District of Columbia have now.

193. Martin, supra note 14, at 116. 
APPENDIX A: BIBLIOGRAPHY OF SCHOLARSHIP

The following is a sample of the scholarship since 1987 :

- John P. Barylick \& Jenna Wims Hashway, Litigation Financing: Preying on Plaintiffs, R.I. BAR JOURNAL, Mar.-Apr. 2011, at 5.

- Bruce L. Beron \& Jason E. Kinsella, David vs. Goliath Patent Cases: A Search for the Most Practical Mechanism of Third Party Litigation Financing for Small Plaintiffs, 38 N. KY. L. REV. 605 (2011).

- Michelle Boardman, Insurers Defend and Third Parties Fund: A Comparison of Litigation Participation, 8 J.L. ECON. \& POL'Y 673 (2012).

- Christy B. Bushnell, Champerty is Still no Excuse in Texas: Why Texas Courts (and the Legislature) Should Uphold Litigation Funding Agreements, 7 Hous. BUS. \& TAX L.J. 358 (2007).

- Michele DeStefano, Nonlawyers Influencing Lawyers: Too Many Cooks in the Kitchen or Stone Soup?, 80 FORDHAM L. REV. 2791 (2012).

- Michael Faure \& Jef De Mot, Comparing Third-Party Financing of Litigation and Legal Expenses Insurance, 8 J.L. ECON. \& POL'Y 743 (2012).

- Grace M. Giesel, Alternative Litigation Finance and the Work-Product Doctrine, 47 WAKE FOREST L. REV. 1083 (2012).

- Stephen Gillers, Waiting for Good Dough: Litigation Funding Comes to Law, 43 AKRON L. REV. 677 (2010).

- Jennifer Gregory, Payday Loans for Lawsuits? Champerty in Illinois, CHI. B. A. REC., Oct. 2008, at 60.

- Jenna Wims Hashway, Litigation Loansharks: A History of Litigation Lending and a Proposal to Bring Litigation Advances Within the Protection of Usury Laws, 17 ROGER WiLLIAMS U. L. REV. 750 (2012).

- Bert I. Huang, Litigation Finance: What do Judges Need to Know?, 45 COLUM. J.L. \& SOC. PROBS. 525 (2012).

- Keith N. Hylton, The Economics of Third-Party Financed Litigation, 8 J.L. ECON. \& POL'Y 701 (2012). 
- Jeremy Kidd, To Fund or Not to Fund: The Need for SecondBest Solutions to the Litigation Finance Dilemma, 8 J.L. ECON. \& POL'Y 613 (2012).

- Jennifer Anglim Kreder \& Benjamin A. Bauer, Litigation Finance Ethics: Paying Interest, 2013 J. PROF'L LAw. 1 (2013).

- Christopher B. Little, Third-Party Litigation Funding: Understanding the Risks, COLO. LAW., Apr. 2011, at 69.

- Geoffrey J. Lysaught \& D. Scott Hazelgrove, Economic Implications of Third-Party Litigation Financing on the U.S. Civil Justice System, 8 J.L. ECON. \& POL'Y 645 (2012).

- Julia H. McLaughlin, Litigation Funding: Charting a Legal and Ethical Course, 31 VT. L. REV. 615 (2007).

- Marco de Morpurgo, A Comparative Legal and Economic Approach to Third-Party Litigation Funding, 19 CARDOZO J. INT'L \& COMP. L. 343 (2011).

- Susan Lorde Martin, Financing Litigation On-Line: Usury and Other Obstacles, 1 DePAul Bus. \& COM. L.J. 85 (2002).

- Susan Lorde Martin, Financing Plaintiffs' Lawsuits: An Increasingly Popular (and legal) Business, 33 U. MiCH. J.L. REFORM 57 (2000).

- Susan Lorde Martin, Litigation Financing: Another Subprime Industry that Has a Place in the United States Market, 53 VILL. L. REV. 83 (2008).

- Susan Lorde Martin, Syndicated Lawsuits: Illegal Champerty or New Business Opportunity?, 30 AM. Bus. L.J. 485 (1992).

- Susan Lorde Martin, The Litigation Financing Industry: The Wild West of Finance Should be Tamed not Outlawed, 10 FORDHAM J. CORP. \& FIN. L. 55 (2004).

- Ronald C. Minkoff \& Andrew D. Patrick, Taming the Champerty Beast: A Proposal for Funding Class Action Plaintiffs, 15 No. 1 Prof. LAW. 1, 1 (2004).

- Jonathan T. Molot, Litigation Finance: A Market Solution to a Procedural Problem, 99 GEO. L.J. 65 (2010).

- Stuart L. Pardau, Alternative Litigation Financing: Perils and Opportunities, 12 U.C. DAVIS BUS. L.J. 65 (2011).

- Jonathan D. Petrus, Legal and Ethical Issues Regarding Third-Party Litigation Funding, L.A. LAw., Nov. 2009, at 16.

- Douglas R. Richmond, Other People's Money: The Ethics of Litigation Funding, 56 MERCER L. REV. 649 (2005). 
- Cassandra Burke Robertson, The Impact of Third-Party Financing on Transnational Litigation, 44 CASE W. RES. J. INT'L L. 159 (2011).

- Paul H. Rubin, Third-Party Financing of Litigation, 38 N. KY. L. REV. 673 (2011).

- Anthony J. Sebok, Betting on Tort Suits After the Event: From Champerty to Insurance, 60 DEPAUL L. REV. 453 (2011).

- Anthony J. Sebok, The Inauthentic Claim, 64 VAND. L. REV. 61 (2011).

- Yifat Shaltiel \& John Cofresi, Litigation Lending for Personal Needs Act: A Regulatory Framework to Legitimatize Third Party Litigation Finance, 58 CONSUMER FIN. L. Q. REP. 347 (2004).

- Joanna M. Shepherd, Ideal Versus Reality in Third-Party Litigation Financing, 8 J.L. ECON. \& POL’Y 593 (2012).

- Mark J. Shukaitis, A Market in Personal Injury Tort Claims, 16 J. LEGAL STUD. 329 (1987).

- Maya Steinitz, The Litigation Finance Contract, 54 WM. \& MARY L. REV. 455 (2012).

- Maya Steinitz, Whose Claim is this Anyway? Third-Party Litigation Funding, 95 MINN. L. REV. 1268 (2011).

- George Steven Swan, Economics and the Litigation Funding Industry: How Much Justice Can You Afford?, 35 NEW ENG. L. REV. 805 (2001).

- George Steven Swan, The Economics of Usury and the Litigation Funding Industry: Rancman v. Interim Settlement Funding Corp., 28 OKLA. City U. L. ReV. 753 (2003).

- Stephen C. Yeazell, Re-Financing Civil Litigation, 51 DePAUl L. REV. 183 (2001).

The following is a sample of commentary written by students since 1990:

- Donald L. Abraham, Note, Investor-Financed Lawsuits: A Proposal to Remove Two Barriers to an Alternative Form of Litigation Financing, 43 SYRACUSE L. REV. 1297 (1992).

- Sheri P. Adler, Note, Alternative Litigation Finance and the Usury Challenge: A Muli-Factor Approach, 34 CARDOZO L. REV. 329 (2012). 
- Courtney R. Barksdale, Note, All that Glitters Isn't Gold: Analyzing the Costs and Benefits of Litigation Finance, 26 REV. LITIG. 707 (2007).

- Nicholas Beydler, Comment, Risky Business: Examining Approaches to Regulating Consumer Litigation Funding, 80 UMKC L. REV. 1159 (2012).

- Paul Bond, Comment, Making Champerty Work: An Invitation to State Action, 150 U. PA. L. REV. 1297 (2002).

- Daniel C. Cox, Comment, Lawsuit Syndication: An Investment Opportunity in Legal Grievances, 35 ST. LoUIS U. L.J. 153 (1990).

- Nicholas Dietsch, Note, Litigation Financing in the U.S., the U.K., and Australia: How the Industry has Evolved in Three Countries, 38 N. KY. L. REV. 687 (2011).

- Ari Dobner, Comment, Litigation for Sale, 144 U. PA. L. REV. 1529 (1996).

- Tripp Dubose, Comment, Consumer Legal Funding in Alabama, 36 J. LeGAL PROF. 529 (2012).

- Martin J. Estevao, Note, The Litigation Financing Industry: Regulation to Protect and Inform Consumers, 84 U. COLO. L. REV. 467 (2013).

- Lauren J. Grous, Note, Causes of Action for Sale: The New Trend of Legal Gambling, 61 U. MIAMI L. REV. 203 (2006).

- Diane Hellwig, Note, Exposing the Loansharks in Sheep's Clothing: Why Re-Regulating the Consumer Credit Market Makes Economic Sense, 80 NOTRE DAME L. REV. 1567 (2005).

- Jason Lyon, Comment, Revolution in Progress: Third-Party Funding of American Litigation, 58 UCLA L. REV. 571 (2010).

- Isaac Marcushamer, Note, Selling Your Torts: Creating a Market for Tort Claims and Liability, 33 HOFSTRA L. REV. 1543 (2005).

- Heather A. Miller, Note, Don't Just Check "Yes" or "No": The Need for Broader Consideration of Outside Investment in the Law, 2010 U. ILL. L. REV. 311 (2010).

- Patrick T. Morgan, Note, Unbundling Our Tort Rights: Assignability for Personal Injury and Wrongful Death Claims, 66 Mo. L. REV. 683 (2001). 
- Susan Northway, Note, Non-Traditional Class Action Financing and Traditional Rules of Ethics: Time for a Compromise, 14 GeO. J. LEGAL ETHICS 241 (2000).

- Ross Q. Panko, Note, Accrued Financial Services, Inc. v. Prime Retail, Inc.: Resurrecting Barratry Imposed Detour on Road to Modernization of Maryland Contracts Jurisprudence, 62 MD. L. REV. 361 (2003).

- Mariel Rodak, Comment, It's About Time: A Systems Thinking Analysis of the Litigation Finance Industry and its Effect on Settlement, 155 U. PA. L. REV. 503 (2006).

- Kingston White, Note, A Call for Regulating Third-Party Divorce Litigation Funding, 13 J.L. \& FAM. STUD. 395 (2011). 
APPENDiX B: Proposed Model StATUTE

\title{
Proposed Nonrecourse Civil Litigation Transaction Reform Act
}

\author{
$\S 1$. Short Title \\ This title may be cited as the "Nonrecourse Civil Litigation Transac- \\ tion Reform Act."

\section{§ 2. Definitions} \\ As used in this title - \\ a) "Consumer" means a person or entity who has a pending civil \\ claim or action and who enters into a nonrecourse civil litiga- \\ tion transaction with a Litigation Finance Company. \\ b) "Litigation Finance Company" means a person or entity that \\ enters into a nonrecourse civil litigation transaction with a \\ consumer. \\ c) "Nonrecourse civil litigation transaction" means a transaction \\ in which a Litigation Finance Company makes a cash pay- \\ ment to a consumer in exchange for the right to receive an \\ amount out of the potential proceeds of any realized settle- \\ ment, judgment, verdict, or award the consumer may receive \\ in a civil claim or action. This definition does not include the \\ advancing of expenses of litigation made by attorneys on be- \\ half of their clients as permitted by Rule 1.8(e) of the Ameri- \\ can Bar Association Model Rules of Professional Conduct or \\ the equivalent rule of the jurisdiction where the transaction \\ occurs. If no proceeds in the civil claim or action are received \\ the consumer is not required to repay the Litigation Finance \\ Company.
}

\section{§3. Requirements for Nonrecourse Civil Litigation Transaction \\ Contracts}

All nonrecourse civil litigation transactions shall comply with the following requirements:

a) All nonrecourse civil litigation transaction contracts must be in writing, and must be written in a clear and coherent manner using words with common, everyday meanings that will enable an average consumer who makes a reasonable effort under ordinary circumstances to read and understand the terms of the transaction without having to obtain the assistance of a 
professional. The contract must have a meaningful arrangement that is appropriately divided and captioned by its various sections.

b) All contracts must be completely filled in and must contain the following disclosure statement on the front page in at least twelve point bold type:

\section{Disclosure Statement}

Total amount to be advanced to consumer under this contract: $\$$

$\begin{array}{ll}\begin{array}{l}\text { Itemized Fees: } \\ \text { application }\end{array} & \$ \\ \text { processing } & \$ \\ \text { attorney review } & \$ \\ \text { broker } & \$ \\ \text { other } & \$ \\ \text { Total fees: } & \$\end{array}$

Annual percentage fee (rate of return) on advance, compounded monthly: $\%$

Total amount to be repaid by consumer

$\begin{array}{ll}\text { if at } 6 \text { months: } & \$ \\ \text { if at } 12 \text { months: } & \$ \\ \text { if at } 18 \text { months: } & \$ \\ \text { if at } 24 \text { months: } & \$ \\ \text { if at } 36 \text { months: } & \$\end{array}$

c) All contracts shall provide that the consumer may cancel the contract within five business days following the consumer's receipt of funds without penalty or further obligation.

The contract shall contain the following notice written in a clear and conspicuous manner:

Consumer's right to cancellation: You may cancel this contract without penalty or further obligation within five business days from the date you receive funding from the Litigation Finance Company. 
The contract shall also state that in order for the cancellation to be effective, the consumer must either: (i) return the full amount of disbursed funds to the Litigation Finance Company by delivering the Litigation Finance Company's uncashed check to the Litigation Finance Company's office in person within five business days of the disbursement of funds; or (ii) mail a notice of cancellation and include in that mailing a return of the full amount of disbursed funds in the form of the Litigation Finance Company's uncashed check, a registered check, a certified check, or a money order, by insured, registered, or certified United States mail, postmarked within five business days after receiving funds from the Litigation Finance Company, to the address specified in the contract to send cancellation notices.

d) The consumer shall initial each page of the contract.

e) The contract shall contain the following statement in at least twelve point bold type:

The Litigation Finance Company agrees that it shall have no right to and will not make any decisions with respect to the conduct of the underlying civil claim or action or any settlement or resolution of the underlying civil claim or action. The right to make those decisions remains solely with you and your attorney in the civil claim or action.

f) The contract shall contain an acknowledgment by the consumer that the consumer has reviewed the contract in its entirety.

g) The contract shall contain the following statement in at least twelve point bold type located immediately above the place on the contract where the consumer's signature is required:

Litigation Finance Companies must register with regulators in your jurisdiction. Before signing this contract, verify the Litigation Finance Company's registration.

The consumer has been advised and instructed by the Litigation Finance Company that the consumer should seek this funding from sources other than the Litigation Finance Company including but not limited to banks, credit cards, family, or friends.

The consumer has been advised by the Litigation Financing Company that the Litigation Financing Company is a provider of funds of last resort and that other sources of funds or financing, if available, would likely be less expensive.

Do not sign this contract before you read it completely or if it contains any blank spaces. You are entitled to a completely filled in copy of this contract. Before signing this contract you should obtain the 
advice of an attorney. You may also want to consult with a tax professional, financial professional, or both.

h) The contract shall contain a written acknowledgement by the attorney representing the consumer in the underlying civil claim or action that states the following:

1) The attorney representing the consumer in the underlying civil claim or action has reviewed the contract and all costs and fees have been disclosed including the annualized rate of return applied to calculate the amount to be paid by the consumer;

2) The attorney representing the consumer in the underlying civil claim or action is being paid on a contingency basis pursuant to a written fee agreement;

3) All proceeds of the underlying civil claim or action will be disbursed from the trust account of the attorney representing the consumer in the underlying civil claim or action, or a settlement fund established to receive the proceeds of the underlying civil claim or action from the defendant on behalf of the consumer;

4) The attorney representing the consumer in the underlying civil claim or action is following the written instructions of the consumer with regard to the nonrecourse civil litigation transaction;

5) The attorney representing the consumer in the underlying civil claim or action shall not be paid or accept an offer to be paid commissions or referral fees; and

6) Whether the attorney representing the consumer in the underlying civil claim or action does or does not have a financial interest in the Litigation Finance Company.

i) The contract shall contain the following statement in at least twelve point bold type:

If there is no recovery of any money from your underlying civil claim or action or if there is not enough money to pay the Litigation Finance Company back in full, you will not owe the Litigation Finance Company anything in excess of your recovery unless you have violated this agreement. 
j) For English-speaking and Spanish-speaking consumers, contracts must be written in the same language in which the oral negotiations are conducted between the Litigation Finance Company and the consumer. For consumers whose primary language is neither English nor Spanish, the principal terms of the contract must be translated by a certified translator in the consumer's native language and the translator must sign a notarized affirmation confirming that the principal terms have been presented to the consumer in the consumer's native language and acknowledged by the consumer in writing. Principal terms must include all of the items required to be disclosed by this section.

k) To the extent the contract provides for attorneys' fees and costs in addition to the amount due and owing under the contract, the contract must provide that in case of a breach of the contract by either party, attorneys' fees and costs may be recoverable by the prevailing party and must be reasonable. Any contractual cap on such attorneys' fees and costs must apply equally to both parties.

1) No contract may require mandatory arbitration to resolve disputes under the contract.

m) Nothing contained in the contract shall be construed so as to deprive any individual of any private right of action under the law.

n) Nothing contained in the contract shall be construed as relieving the Litigation Finance Companies of their obligations to comply with all state and federal statutes, regulations, or rules, to the extent such statutes, regulations, or rules are applicable to and govern any particular contract, nor shall any of the provisions of the contract be deemed permission to engage in any act or practice prohibited by such statute, regulation, or rule, to the extent such statute, regulation, or rule is applicable to and governs any particular contract.

\section{§ 4. Fee Requirements}

a) A Litigation Finance Company shall not assess fees for any period exceeding thirty-six months from the date of the contract with the consumer. 
b) Fees assessed by a Litigation Finance Company may compound semiannually but may not compound based on any lesser time period.

c) In calculating the annual percentage fee or rate of return, a Litigation Finance Company must include all charges payable directly or indirectly by the consumer, and must compute the rate based only on amounts actually received and retained by the consumer.

\section{§ 5. Registration of Litigation Finance Companies}

A Litigation Finance Company shall not enter into a nonrecourse civil litigation transaction with a consumer in any State, Territory, or the District of Columbia without first registering pursuant to the laws of the State, Territory, or the District of Columbia.

\section{$\S$ 6. Prohibit Acts by Litigation Finance Companies}

a) The Litigation Finance Company shall not pay or offer to pay commissions or referral fees to any attorney or employee of a law firm, or to any medical provider, chiropractor, or physical therapist or their employees for referring a consumer to the Litigation Finance Company.

b) The Litigation Finance Company shall not accept any commissions, referral fees, or rebates from any attorney or employee of a law firm or any medical provider, chiropractor, or physical therapist or their employees.

c) The Litigation Finance Company shall not advertise false or intentionally misleading information regarding its product or services.

d) The Litigation Finance Company shall not knowingly provide nonrecourse civil litigation funding to a consumer who has previously sold or assigned all or part of the consumer's potential proceeds from the underlying civil claim or action to another Litigation Finance Company without first buying out that Litigation Finance Company's entire accrued balance unless otherwise agreed in writing by the Litigation Finance Companies and the consumer.

\section{$\S 7$. Effect of Communication on Attorney Client Privilege}

No communication between the attorney and the Litigation Finance Company as it pertains to the nonrecourse civil litigation transaction shall 
limit, waive, or abrogate the scope or nature of any statutory or commonlaw privilege, including the work-product doctrine and the attorney-client privilege.

\section{§ 8. Administrative Enforcement}

a) The Consumer Financial Protection Bureau shall be authorized to issue rules, regulations, or both to enforce the provisions of this title.

b) The authority of the Consumer Financial Protection Bureau includes but is not limited to conducting investigations and initiating enforcement actions to enforce the provisions of this title.

\section{§ 9 Relation to State Laws}

This title does not annul, alter, affect, or exempt any person or entity subject to the provisions of this title from complying with the laws of any State, Territory, or the District of Columbia with respect to nonrecourse civil litigation transactions, except to the extent that those laws are inconsistent with any provision of this title, and then only to the extent of the inconsistency. For the purposes of this section, a law of a State, Territory, or the District of Columbia is not inconsistent with this title if the protection that law affords to a consumer is greater than the protection provided by this title. 